\title{
Ordovician cold water brachiopods from the Ougarta Mountain Range, Algerian Sahara
}

\author{
Leonid E. Popov, Philippe Legrand, Boumedienne Bouterfa \& Mansoureh Ghobadi Pour
}

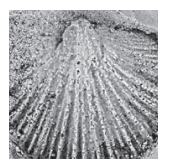

\begin{abstract}
In the Mid to Late Ordovician the area of the Ougarta Range in north-west Africa occupied a position in relative proximity to the South Pole. Eight successive low diversity brachiopod faunas, including the lingulide association dominated by unnamed species of Lingulobolus, the Darriwilian ?Sivorthis fraterna and Tissintia convergens, the Sandbian to early Katian Drabovinella regia and Tafilaltia destombesi-Rostricellula ambigena associations, the mid Katian Drabovinella maxima and Svobodaina cf. havliceki associations and the late Hirnantian Plectothyrella crassicostis chauveli Association are recognised. The brachiopod based correlation with the Middle to Upper Ordovician succession of the Anti-Atlas in Morocco, suggests the presence of some gaps in the Ougarta section. The occurrence of Svobodaina cf. havliceki in the Bou M'Haoud Formation Upper Member suggests its correlation with the upper part of the Lower Ktoua Formation of the Anti-Atlas. Among the other brachiopod taxa Drabovinella regia, Orbiculothyris cf. costellata, Tafilaltia destombesi, Rostricellula ambigena, together with the genera Fehamya, Mezotreta and Leptaena were previously unknown from Algerian Sahara. Key words: Brachiopoda, Ordovician, taxonomy, biostratigraphy, Algeria, Gondwana.
\end{abstract}

Popov, L.E., Legrand, P., Bouterfa, B. \& Ghobadi Pour, M. 2019. Ordovician cold water brachiopods from the Ougarta Mountain Range, Algerian Sahara. Bulletin of Geosciences 94(1), 41-70 (11 figures, appendix). Czech Geological Survey, Prague. ISSN 1214-1119. Manuscript received September 27, 2018; accepted in revised form January 15, 2019; published online March 11, 2019; issued March 31, 2019.

Leonid E. Popov, Department of Natural Sciences, National Museum of Wales, CF10 3NP, United Kingdom • Philippe Legrand, Retired, 216, cours Général de Gaulle, 33170 Gradignan, France • Boumedienne Bouterfa, Département des Sciences de la Terre, Universté d'Oran 2 Mohamed Ben Ahmed, BP 1015, El M'Naouer, 31000 Oran, Algeria • Mansoureh Ghobadi Pour, Department of Geology, Faculty of Sciences, Golestan University, Gorgan 49138-15739, Iran;mghobadipour@yahoo.co.uk

The name Ougarta Mountain Range (or more simply Ougarta Range; Fig. 1) applies to a mountainous region trending NW-SE and extending for $330 \mathrm{~km}$ on the edge of the platform of the western Algerian Sahara. This range is the result of folding of a thick Palaeozoic succession during the Variscan compression. This range forms a link between the Anti-Atlas and the Saharan basins, thus justifying a comprehensive study.

Inferred reconstructions of the polar wander path suggest that the Ordovician South Pole drifted gradually across the north-west African sector of Gondwana (Torsvik \& Cocks 2011, Torsvik et al. 2012), but without sedimentary evidence in the neighbourhood of the present Ougarta Range except for Hirnantian periglacial sediments. For most of the time this area was flooded by a shallow sea. However, a large part of the Ordovician succession is significantly affected by the fluvioglacial and glacial erosion which occurred during the Hirnantian time (Arbey 1968; Legrand 1974, 1985a; Ghienne et al. 2007). In the Mid to Late Ordovician, this shallow sea was inhabited by a low diversity fauna of which brachiopods form an important component; these brachiopods represented the major objective of the present study.

Although, together with the Anti-Atlas, the Ougarta Range is considered as an important source of the Ordovician macrofossils from the North African sector of Gondwana, the existing record of Ordovician brachiopods in the region is sparse. Roch (1933) was the first to report Ordovician brachiopods in the Ougarta Range. In a short paper he announced a presence of moulds assigned to "Orthis gr. alternata Sowerby - retrostriata M'Coy" in the vicinity of Hassi Chaamba, Daoura. Some months later Menchikoff (1933) reported, this time in the Ougarta Range s.s., two fossiliferous horizons at Kheneg et Tlaïa, the lower one with unidentified brachiopods of presumed Llandeilo age, the upper one with orthides, identified as Orthis redux Barrande, 1848. The whereabouts of the specimens sampled during these pioneering works is presently unknown. Many years later, Poueyto (1951, 1952) cited the same species from Hassi Chamba (Daoura), from Tabelbala and from Kheneg et Tlaïa; also a little farther to the south-east, at Feidj ez Zeidiya, 


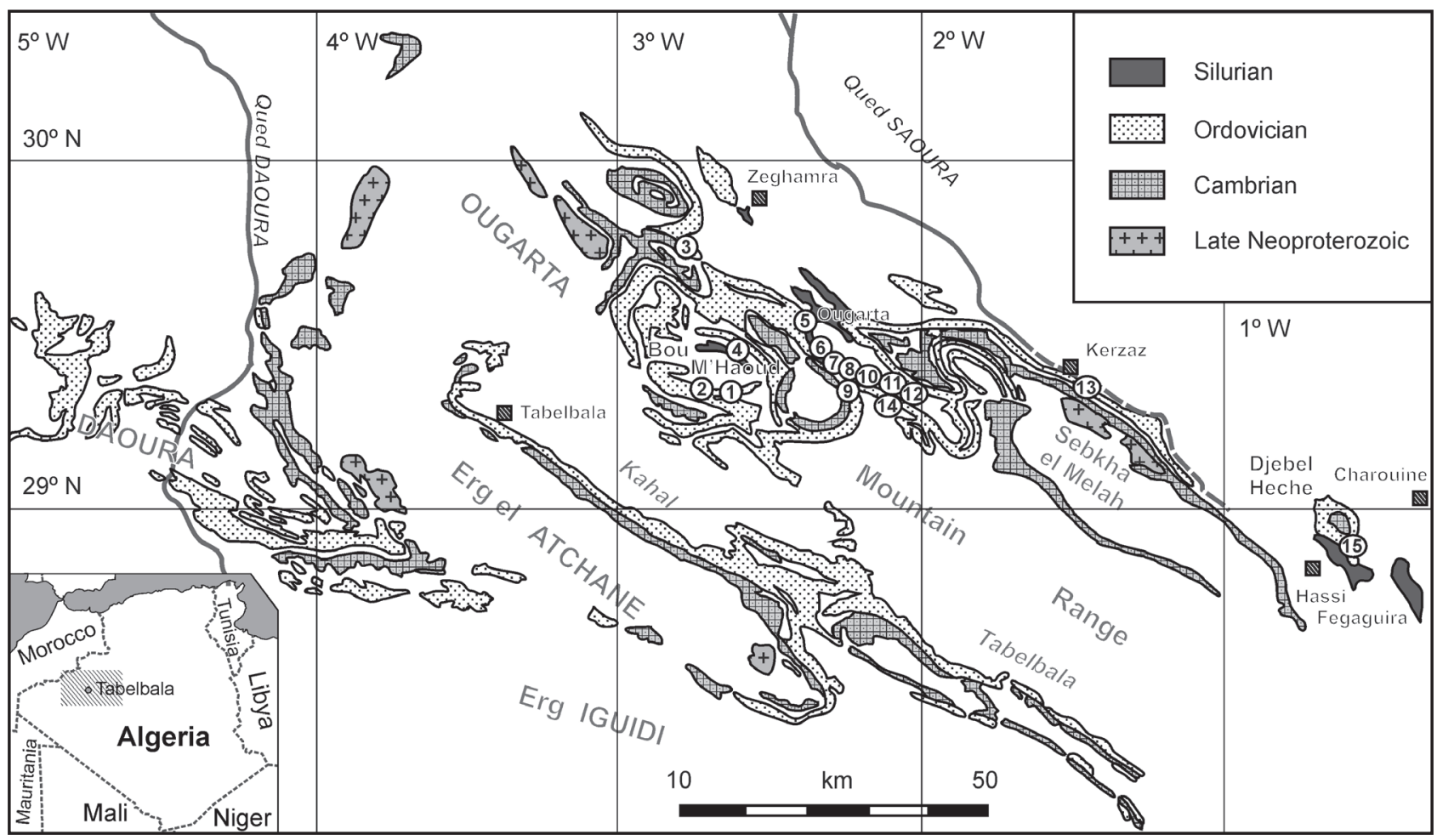

Figure 1. Proterozoic and Lower Palaeozoic outcrops of the Ougarta Range. 1-14 refer to sections studied: 1 - Bou M'Haoud (Ravine, Vicinity, Village); 2 - Bou M'Haoud N-W; 3 - Kheneg et Tlaïa; 4 - Djebel Barani (Hassi Talamt); 5 - Oum el Baraï; 6 - El Mizane; 7 - Kheneg el Aatène; 8 - N-W Foum El Kseib; 9 - Foum Tineslem; 10 - Near Height 472; 11 - Opposite Zmeïlet el Barka; 12 - Opposite to Daïet en Nouguir; 13 - Feidj ez Zeidiya; 14 - Mesdar; 15 - Djebel Hèche. After the Carte géologique du Nord-Ouest de l'Afrique (Feuille n², Maroc-Algérie Ouest 1952, $19^{\text {th }}$ International Geological Congress) (Legrand \& Bouterfa unpublished data).

several beds with brachiopods were documented, two of them contained orthides identified as Orthis redux Barrande. A year before, Poueyto (1950) had reported the presence of some "rhynchonelles" in the Ougarta Ksar Sandstones that was inclined to believe were Gotlandian (i.e. Silurian).

In 1960 at the occasion of the Mission Eurafrep-Prepa (Gómes Silva et al. 1963) brachiopods were found at the top of the Kheneg el Aatène Formation, in the Foum ez Zeidiya Formation and the Bou M'Haoud Formation. Although "rhynchonelles" were recovered from the Ougarta Ksar Formation and dated as Silurian, (but at that time the persculptus zone was recognised as the first graptolite zone of the Silurian System).

The first detailed account of brachiopods from the Ougarta Range can be found in the paper by Legrand (1971) who reported on the occurrence of ?Lingulobolus aff. brimonti (Rouault 1850) in the Darriwilian of Djebel Heche and in Havlíček's (1971) monograph dedicated mainly to the brachiopod faunas of the AntiAtlas, Morocco. Nevertheless, three taxa described in that publication, including Hirnantia sagittifera (M'Coy, 1851), Tissintia convergens Havlíček, 1970 and Plectothyrella crassicostis chauveli Havlíček, 1971 were partly based on the samples derived from the Ougarta Range, which was frequently overlooked by the subsequent researches. In particular, these are the "rhynchonelles" found by Poueyto that were collected again by Hollard and assigned by Havlíček in Destombes (1968) to Plectothyrella platystrophoides Temple, 1965 then regarded as a new species named Plectothyrella chauveli Havlíček, 1971 (here described as Plectothyrella crassicostis chauveli). These latter were attributed by Destombes (1968) to the upper Ashgill and as terminal Ashgill by Havlíček (1971).

More detailed application of the Algerian brachiopods for regional biostratigraphy became possible only after publication of Havlíček's $(1970,1971)$ papers mainly dedicated to the Ordovician faunas from the adjacent Anti-Atlas region. In 1970 a brachiopod zonation based on these collections was made for the first time (Legrand 1974, 1985a). In particular, the Tissintia convergens Zone ( $v 6$ Zone) was introduced, based on the frequent occurrence of the index-species in the upper part of the Foum ez Zeidiya Formation. Although Plectothyrella chauveli Zone ( $v 9$ Zone) was defined at the top of the Ordovician succession, where this species was sampled with another brachiopod, preliminarily identified as Hirnantia aff. 
sagittifera (M'Coy) (Legrand 1985b). Among the Ordovician brachiopods of North Africa reported by Mergl (1983) seven taxa including Destombesium aff. zagoraense Havlíček, 1971, Destombesium ougartaense Mergl, 1983, Drabovia tenuiseptata Havlíček, 1971, Drabovia sp., Drabovinella maxima Mergl, 1983, Hirnantia sagittifera (M'Coy, 1851) and Orthambonites (= ?Sivorthis) fraternus Havlíček, 1971 are from the Ougarta Range.

The newly available material contains 20 taxa of linguliform and rhynchonelliform brachiopods. Ten of them, including Drabovia cf. tenuiseptata Havlíček, 1971, Drabovinella maxima Mergl, 1983, Drabovinella regia Havlíček, 1971, Hirnantia sagittifera (M'Coy, 1851) Orbiculothyris cf. costellata Wolfart, 1968 in Wolfart et al. (1968), Plectothyrella crassicostis chauveli Havlíček, 1971, ?Sivorthis fraterna (Havlíček, 1971), Svobodaina cf. havliceki Villas, 1985, Tafilaltia destombesi Havlíček, 1970 and Tissintia convergens Havlíček, 1970 were assigned with confidence or provisionally down to the species level. The studied brachiopod collection is representative, but not all-inclusive. In particular, it does not include species of Destombesium described from the Ougarta Range by Mergl (1983). Additionally, the occurrences of Rafanoglossa sp. and Tomasina sp. reported in the uppermost part of the Kheneg el Aatène Formation (Ghienne et al. 2007, fig 4) are not confirmed.

\section{Geological setting}

The Ordovician geology of the Ougarta Range was outlined by Menchikoff (1933), Poueyto (1952), and Arbey (1962) but the first thorough lithostratigraphy was proposed by Gómes Silva et al. (1963). Five major lithostratigraphical units were recognised, in ascending order, including: Foum Tineslem Formation, Kheneg el Aatène Formation, Foum ez Zeidiya Formation, Bou M'Haoud Formation and Djebel Serraf Formation (Fig. 2). The first, sandy, argillaceous, then silty-argillaceous was dated later as Tremadocian by graptolites. The second, chiefly sandy could tally with lower and middle Arenig graptolites, ferruginous at the top (Floian and Dapingian today) except for the upper part that was assigned to

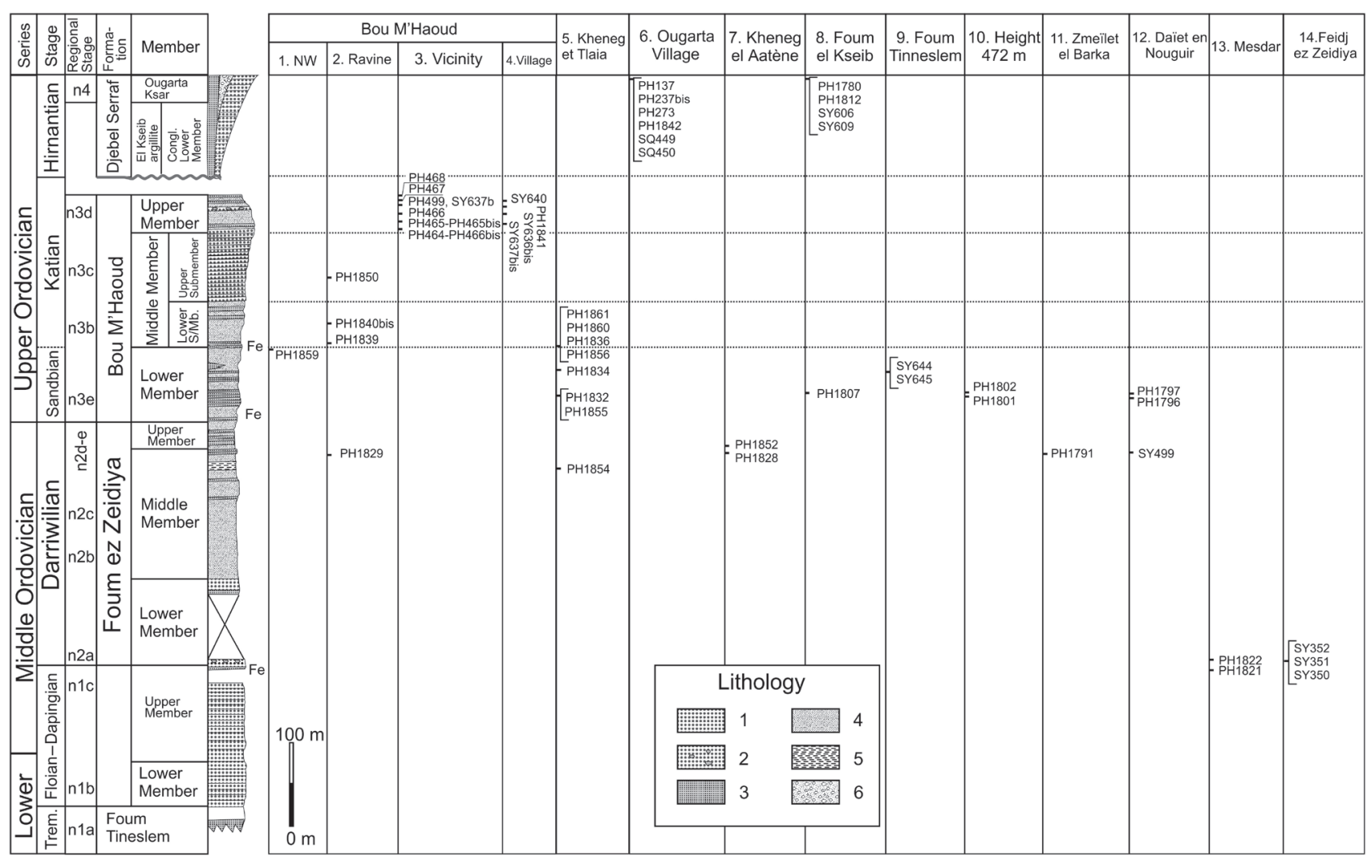

Figure 2. Synthetic log, after Legrand $(1974,1986)$ and Legrand \& Bouterfa (unpublished data), showing generalised Middle to Upper Ordovician sedimentary succession of Ougarta Range, stratigraphical position of fossil horizons in sampled sections, lithostratigraphical units and their correlation with Global Chronostratigraphical Scale. Abbreviations: Fe - position of oolitic ironstone bed with lingulide brachiopods. Trem. - Tremadocian Stage. Legend: 1 - coarse to medium-grained sandstones, rare pebbles; 2 - medium to fine-grained sandstones; 3 - fine-grained sandstones; 4 - argillaceous siltstones with large ovoid concretions; 5 - silty clays; 6 - fluvio-glacial and glacial deposits. 
the late Arenig (lower Darriwilian today) according to the graptolites (hirundo Zone). The third is made, in ascending order, of argillaceous siltstones rarely observed, argillaceous sandstones, argillaceous siltstones with numerous silty, calcareous, ovoid lenses and further siltstones. The formation is topped by sandstones. It was dated as Llanvirn (Darriwilian) by graptolites. Above, most of the Upper Ordovician succession was included into the Bou M'Haoud Formation, while overlying sandy deposits were assigned to the Djebel Serraf Formation.

At that time, while the existence of a general unconformity in the upper part of the Ordovician succession was accepted, its connection with glacial phenomena had not yet been proposed. Moreover, it was poorly characterised; moreover the top of the Bou M'Haoud Formation was improperly placed. Later works (e.g. Legrand 1986), including data here presented, showed that the beds above this limit had no fluvio-glacial or glacial aspect, as expected by the now classical interpretation. Marine fauna from these beds (Legrand in Gómes Silva et al. 1963, Mergl 1983) was not consistent with glacial sediments and did not date the terminal Ordovician glaciation as supposed originally. To conclude, the concept of the Bou M'Haoud Formation where three members were distinguished (Legrand 1986), and its age and its interpretation were thoroughly reviewed. Unfortunately, these corrections were not adopted in more recent papers (e.g. Ghienne et al. 2007). It will be necessary, therefore, to avoid to reference to them about the Bou M'Haoud Formation.

\section{Faunal assemblages and their biostratigraphical signature}

While brachiopods are the most common fossils in the Ordovician of the Ougarta Range their occurrences are rare and discontinuous (Fig. 3); nevertheless, in the absence of other biostratigraphically informative fossils, e.g. graptolites, conodonts and chitinozoans, they are valuable for interregional correlation, especially with Middle to Upper Ordovician deposits of the Anti-Atlas in Morocco, where a brachiopod biostratigraphical succession was described by Havlíček (1971) with variable degrees of accuracy.

Most of the brachiopod taxa described in the paper, with a few noticeable exceptions, are endemic for the North African sector of Gondwana. They inhabited
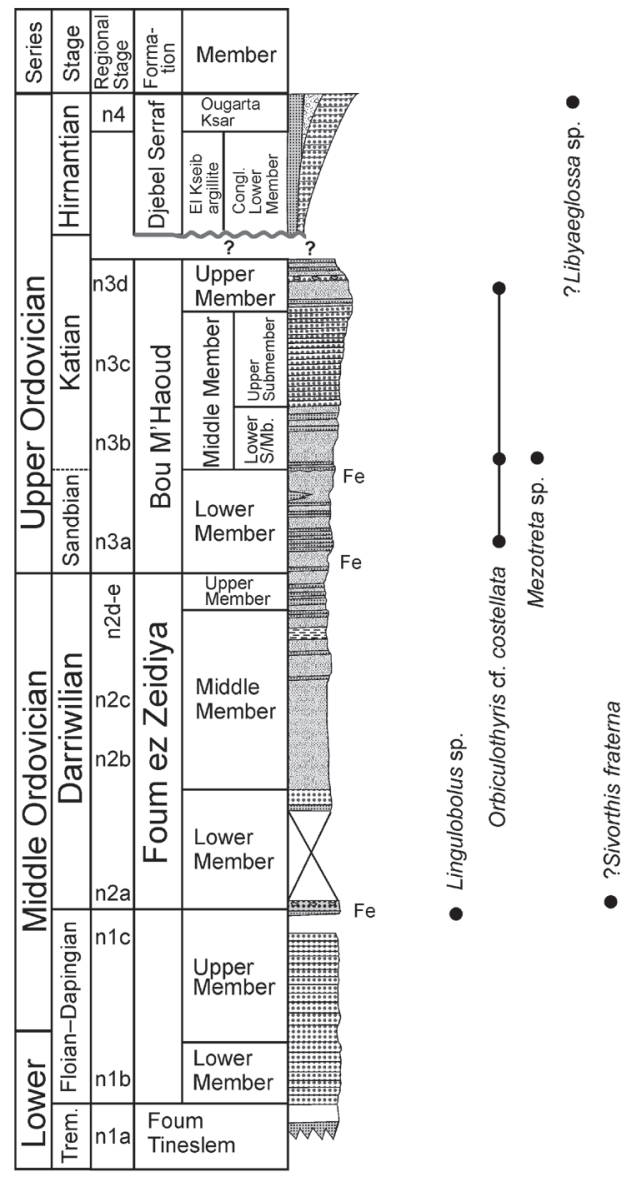

Figure 3. Stratigraphical distribution of brachiopods shown against generalized Middle to Upper Ordovician sedimentary succession of Ougarta Range (after Legrand 1974, 1986; Legrand \& Bouterfa unpublished data). Abbreviaton: $\mathrm{Fe}$ - position of oolitic ironstone beds. Lithological symbols are the same as in Fig. 2. 
a shallow marine environment of storm-dominated shoreface to offshore (Ghienne et al. 2007). Brachiopods form low diversity to monotaxic assemblages, some taxa show opportunistic strategies. As well as collection was originally sampled principally for geological mapping purposes, no detailed palaeocological study was attempted; nevertheless several successive faunal associations can be recognised.

The monotaxic Lingulobolus Association, which occurs in the oolitic ironstones at the top of the Kheneg el Aatène Formation in the south-eastern part of Ougarta Range, is the earliest within the studied biostratigraphical sequence. In Mesdar complete, disarticulated valves of Lingulobolus sp. occur in a shell bed. The genus has a long stratigraphical range from the uppermost Furongian to Darriwilian, while most of the species assigned to Lingulobolus are inadequately known and require revision. Nevertheless, the shells of Lingulobolus sp. from Mesdar are not conspecific with Lingulobolus hawkei (Rouault, 1850) and ?Lingulobolus brimonti (Rouault, 1850) from the Armorican Sandstone Formation of northern France and they are most closely comparable with Lingulobolus affinis (Billings, 1872) from the Bell Island Group of Bell Island, Newfoundland. The latter species require revision; although, its precise stratigraphical range remains unknown, but it is probably confined to the Lower Ordovician.

No brachiopod characterises the Floian interval. The stratigraphical interval from the late Floian to the base of the Darriwilian may coincide with a hypothetical period of significant sediment condensation and widespread hiatuses in the sedimentary succession traceable across the North African and Arabian sectors of Gondwana (GutiérrezMarco et al. 2014, Ghavidel-Syooki et al. 2014a), but that remains to be proven in the Ougarta Range.

The top of the Kheneg el Aatène Formation is dated as Dapingian indirectly on correlation with the ironstone bed in the Feidj ez Zeidiya section, where just above, separated by a disconformity, the base of the Foum ez Zeidiya Formation is dated by the graptolite Corymbograptus v-fractus wieli (late Arenig auctorum Zone, or base of Darriwilian).

A renewal of the fauna comes with this major retrogression in Sahara (Legrand \& Nabos 1962, Legrand 1964, Ghienne et al. 2007). This disconformity was also found in the Moroccan Anti-Atlas (Desmochitina bulla Biozone; Elaouad-Debbaj 1984).

Two geographically separated monotaxic rhynchonelliform brachiopod associations occur in the Foum ez Zeidiya Formation. Among them the ?Sivorthis fraterna Association is confined to the south-eastern part of the Ougarta Range (Foum ez Zeidiya, Mesdar, Jebel Heche), where it occurs in the lower part of the formation, while Tissintia convergens is an opportunistic taxon, which occurs $250 \mathrm{~m}$ higher within the characteristic horizon with occasional thin shell accumulations in the upper part of the Foum ez Zeidiya Formation. The species is known from numerous localities within the central and north-western parts of the Ougarta Range. In the Anti-Atlas both taxa occur within the First Bani Group Havlíček (1971). Tissintia convergens has a very short stratigraphical range confined to the Guezzart Formation (formerly Igzert Formation) of late Darriwilian (auctorum Zone) age, (Havlíček 1971, Gutiérrez-Marco et al. 2003, Destombes 2004). In the Ougarta Range, it is confirmed that the specimens assigned to ?Sivorthis fraterna were collected just above the occurrence of Corymbograptus $v$-fractus wieli of early Darriwilian age, while in the AntiAtlas Range it is confined to the Tachila and Bou Zeroual formations at the base of the First Bani Group (Havlíček 1971) dated as the late Darriwilian (Gutiérrez-Marco et al. 2003), so its occurrences in Algeria and Morocco are distinctly diachronous.

The base of the Bou M'Haoud Formation is underlined by slightly disconformable ferruginous deposits. After a short regression, the facies of the Bou M'Haoud Formation Lower Member become more detritic, more littoral and more variable depending on the locality. The fauna is limited in places to small bivalves and gastropods preserved as moulds. In other places, beds sometimes with the aspect of hard-grounds contain some brachiopods. The Darriwilian brachiopod fauna is succeeded by the oligotaxic Drabovinella regia Association, but actually, fossils are very rare. In addition to the index-taxon the faunal assemblage includes Drabovia cf. tenuiseptata as a relatively common taxon, while Orbiculothyris cf. costellata, ?Fehamya sp. and ?Hirnantia sp. 1 is represented by a few specimens collected from a single locality. The brachiopod localities with the taxa characteristic of the Drabovinella regia Association are scattered across the central part of the Ougarta Range and almost entirely confined to the Lower Member of the Bou M'Haoud Formation. The age of this association is uncertain and probably ranges from Sandbian to early Katian. This correlation is based mainly on the occurrences of Drabovinella regia and Drabovia tenuiseptata in the Anti-Atlas where they are known from the middle part of the Lower Ktaoua Formation (Havlíček 1971). The position of the Sandbian-Katian boundary in the Ougarta Range cannot be defined precisely, but the brachiopod fauna, which occurs in the Bou M'Haoud Formation Lower Member, is probably not older than the uppermost Sandbian and at least in part may be of Katian age.

The oligotaxic Tafilaltia destombesi-Rostricellula ambigena Association is known from a few localities in the lower part of the Bou M'Haoud Formation Middle Member at Kheneg et Tlaïa (and at a little higher level at the entrance of the Bou M'Haoud Ravine). 
In addition to the eponymous species it contains Drabovia cf. tenuiseptata, and linguliform brachiopods Mezotreta sp. and Orbiculothyris cf. costellata. Tafilaltia destombesi is known in the middle part of the Lower Ktaoua Formation of Anti-Atlas where it forms an almost monotaxic association (Colmenar \& Álvaro 2015), thus an early Katian age for the assemblage is most likely; however, the possibility of a latest Sandbian age cannot be completely excluded. The late Katian age proposed by Ghienne et al. (2007) for the beds with this fauna is not accepted herein. Rostricellula ambigena is another distinctive taxon which is widespread from the upper Sandbian to Katian across Mediterranean Gondwana (Havlíček 1961, Colmenar \& Álvaro 2015) and possibly also occurs in the Chahgonbad Formation (Katian) of the Pol-e Khavand area in Central Iran (Popov et al. 2015), but due to a long biostratigraphical range its application for precise correlation is rather limited.

The upper submember of the Bou M'Haoud Formation Middle Member has no distinct brachiopod fauna and therefore biostratigraphicaly is not characterised.

The Drabovinella maxima Association is known from a few localities at Bou M'Haoud, where it is confined entirely to the Bou M'Haoud Formation Upper Member. Drabovinella maxima is a distinctive, but endemic taxon unknown outside the Ougarta Range, although other associated species, including Drabovia sp. and ?Hirnantia sp. 2 are not biostratigraphically useful.

The Svobodaina cf. havliceki Association is known from a single locality in the upper part of the Bou M'Haoud Formation Upper Member at the vicinity of the Bou M'Haoud Village. The only other brachiopod, which occurs in the association is Drabovia sp. Svobodaina cf. havliceki is probably conspecific with the taxon widespread across the Mediterranean Gondwana (for summary see Colmenar et al. 2014) within the narrow biostratigraphical range. In Spain it is an eponymous taxon for the local brachiopod biozone (Villas 1985), while in the Iranian Zagros Ranges it occurs in the upper part of the Acanthochitina barbata Zone (Ghavidel-Syooki et al. 2014b). Thus brachiopod based correlation suggests that the highest bed of the Bou M'Haoud Formation is middle Katian in age. Therefore the Upper Member at least in a part, could be isochronous with the Upper Tiouririne Formation.

The upper Hirnantian Plectothyrella crassicostis chauveli Association is recognised by the presence of its dominant taxon. Other associated brachiopods are Hirnantia sagittifera and ?Leptaena sp. The Association is known from a number of localities in the upper part of the Djebel Serraf Formation at the vicinity of the Ougarta Village and Foum El Kseib. Havlíček (1971) and Mergl (1983) reported also on the occurrence of Hirnantia sagittifera at Jebel Heche in the south-eastern Ougarta
Range. Hirnantia sagittifera is among the most distinctive brachiopods of the Hirnantia Fauna, which has almost global distribution, while Plectothyrella crassicostis chauveli is confined to the high latitude Bani Province (Villas et al. 1998).

\section{Systematic palaeontology}

Whereabouts of most of the brachiopod samples collected by the geologists of Prepa and Eurafrep in 1960-1961 are unknown today thus only a few of them were available for study. The most significant part of the brachiopod collection presently available was assembled by Legrand as geologist of C.F.P(A) [Compagnie Française des Pétroles (Algérie)] and of Total Algerie between 1961 and 1986. Legrand and Bouterfa carried out additional collections in 2006, 2009 and 2012. The specimens illustrated and discussed in the paper are housed for the time in the Pole Collection University Lyon 1 (France) but will be housed for good in the Museum of Oran University 2 (C.U.O.R).

Types to the Ordovician brachiopod taxa from Morocco described and illustrated by Havlíček $(1970,1971)$ are housed in Laboratoire paléntologique du Service geologique do Maroc at Rabat (Havlíček 1971); however, collection number and individual specimen numbers are not available.

Abbreviations for parameters measured on specimens. $\mathrm{L}=$ maximum length of shell; $\mathrm{Lv}=$ maximum length of ventral valve; $\mathrm{Ld}=$ maximum length of dorsal valve; $\mathrm{W}=$ maximum width of shell; $\mathrm{T}=$ maximum depth of the valve; Iw = maximum width of interarea; PIl, PIw = length and width of pseudointerarea; $\mathrm{B}=$ distance from the umbo to the area of maximum valve width; $\mathrm{Ml}=$ length of muscle field; $\mathrm{Mw}=$ width of muscle field; $\mathrm{BBl}=$ brachiophore length; $\mathrm{BBw}=$ distance between outer margins of brachiophores; $\mathrm{Sl}=$ distance from the umbo to anterior termination of median ridge; $\mathrm{X}=$ mean; $\mathrm{S}=$ standard deviation from the mean; $\max .=$ maximum observed size; min. $=$ minimum observed size; $\mathrm{n}=$ number of specimens. All measurements are in millimetres.

Class Lingulata Gorjansky \& Popov, 1985

Order Lingulida Waagen, 1885

Superfamily Linguloidea Menke, 1828

Family Obolidae King, 1846

Subfamily Obolinae King, 1846

\section{Genus Lingulobolus Matthew, 1895}

Type species. - By original designation ?Lingulella affinis Billings, 1872. 
Lingulobolus sp.

Figure 4A-I

Material. - Nine variably exfoliated ventral valves, including: CUOR $100(\mathrm{Lv}=23.5, \mathrm{~W}=20.7, \mathrm{~T}=4.0, \mathrm{~B}=$ 16.2; Fig. 4H), CUOR 101, CUOR $102(\mathrm{Lv}=22.9, \mathrm{~W}=$ 19.8, $\mathrm{T}=3.5, \mathrm{~B}=15.3$; Fig. 4I), CUOR 103, CUOR 104, CUOR $105(\mathrm{Lv}=19.9, \mathrm{~W}=15.7, \mathrm{~T}=2.5, \mathrm{~B}=13.6, \mathrm{Vl}=$ 11.3; Fig. 4C), CUOR 107 ( $\mathrm{Lv}=15.8, \mathrm{~W}=12.2, \mathrm{~T}=2.3$, $\mathrm{B}=9.5, \mathrm{Vl}=8.2$; Fig. 4E), CUOR $114(\mathrm{Lv}=22.9, \mathrm{~W}=$ $19.8, \mathrm{~T}=3.5, \mathrm{~B}=14.5$; Fig. 4F), CUOR 106, plus one ventral internal mould, CUOR $347(\mathrm{Lv}=15.0, \mathrm{~W}=12.7$, $\mathrm{B}=14.5, \mathrm{PIl}=2.5, \mathrm{PIw}=5.0$ ), ventral internal mould; nine dorsal valves, including: CUOR 108, CUOR 109 (Fig. 4A), CUOR 110, CUOR $111(\mathrm{Ld}=14.3, \mathrm{~W}=12.8$, $\mathrm{T}=3.2, \mathrm{~B}=9.5$; Fig. $4 \mathrm{G})$, CUOR $112(\mathrm{Ld}=13.4, \mathrm{~W}=$ 10.0, $\mathrm{T}=1.6, \mathrm{~B}=8.5$ ), CUOR 113 (Fig. 4B), CUOR 115 $(\mathrm{Ld}=17.4, \mathrm{~W}=14.0, \mathrm{~T}=3.1, \mathrm{~B}=10.0), \mathrm{CUOR} 116(\mathrm{Ld}$ $=17.8, \mathrm{~W}=17.4, \mathrm{~B}=9.5, \mathrm{Vl}=10.5)$, CUOR 117; from locality PH1821, Mesdar, Kheneg el Aatène Formation, Upper Member (Dapingian).

Description. - Shell subequally biconvex to slightly dorsibiconvex, subtriangular, slightly elongate, with divergent, gently curved lateral sides and broadly rounded anterior margin, on average $120 \%(\mathrm{~S}=7.0$; $\mathrm{min} .=114 \%$, max. $=130 \%, \mathrm{n}=5$ ) as long as wide with the maximum width at $66 \%(\mathrm{~S}=1.0 ; \min .=16 \%$, $\max .=19 \%, \mathrm{n}=5)$ from the umbo, between anterior margin and mid-length. Anterior commissure rectimarginate. Ventral valve subacuminate with pointed umbo and a short, narrow, subtriangular, orthocline pseudointerarea. Its sagittal profile evenly convex, on average $18 \%(\mathrm{~S}=4.0$; min. $=$ $60 \%$, max. $=69 \%, \mathrm{n}=5$ ) as high as valve length.

Pedicle groove narrow with steep lateral margin divergent anteriorly (Fig. 4D-F). Propareas wide, raised above the valve floor and bisected by faint divergent flexure lines (Fig 4D).

Dorsal valve on average $118 \%(\mathrm{~S}=11.0$; $\mathrm{min} .=102 \%$, $\max =134 \%, \mathrm{n}=5$ ) with moderately convex lateral profile on average $20 \%(\mathrm{~S}=4.0$; $\min .=16 \%$, max. $=$ $22 \%, \mathrm{n}=3$ ) with a maximum height slightly posterior to mid-length. Dorsal pseudointerarea low, crescentic with a broad groove. Shell surface ornamented with faint, crowded concentric filae and up to 12 thin growth lamellae significantly increasing in number in the posterior half of full-grown shells (Fig. 4H). Dense, faint radial striation, observed on the exfoliated shells (Fig. $4 C, E$ ), indistinguishable on the external surface of wellpreserved specimens (Fig. 4H).

Ventral interior with a visceral area distinctly raised anteriorly, about $67-72 \%$ as long as the valve, with a pair of large, elevated anteromedial muscle fields representing combined scars of outside lateral, middle lateral and central muscles. Combined scars of ventral transmedian and anterior lateral muscles scars on a pair of oblique, strong ridges bounding the posterolateral margins of the visceral area. Umbonal muscle scares weakly impressed, paired, elongate, suboval. Mantle canal system saccate with strongly impressed vascula lateralia straight and slightly divergent proximally, gently curved and convergent distally, with numerous, dense vascula terminalia diverging almost under the right angle outward and inward. Dorsal valve with weakly impressed visceral area extending anteriorly about $60 \%$ of valve length with closely-placed, gently impressed central and anterior lateral muscle scars, divided by a very faint median ridge. Other muscle scars and mantle canals not observed.

Remarks. - The specimens of Lingulobolus sp. show close similarity to Lingulobolus affinis (Billings, 1872) in shell size, proportions, sagittal profile of both valves and observed characters of visceral areas, mantle canals and muscle scars; however, they are left in open nomenclature, because interior of the dorsal valve of the Algerian specimens is incompletely known. Moreover, some species currently assigned to Lingulobolus, including the type species, require substantial revision. Walcott (1912, p. 432) pointed that dense, rounded radial striae are observed on exfoliated shell of Lingulobolus affinis; however, from his description remains uncertain if faint radial ornament is present also on the external shell surface, which is definitely not the case in the Algerian shells. It is also likely that Lingulobolus spissus (Billings, 1872), which according to Walcott (1912) co-occurs together with Lingulobolus affinis in the Bell Island Group of the Bell Island, Newfoundland, most probably represents a junior objective synonym of the latter taxon.

Lingulobolus hawkei (Rouault, 1850) originally described without illustration from the Armorican Sandstone Formation of Brittany and Normandy, and the Budleigh Salterton Pebble Bed of Cornwall. Cocks \& Lockley (1981), and Cocks (2008) confirmed the attribution of the species to Lingulobolus; however, the type material was not examined by these authors and current concept of the taxon is based mainly on descriptions and illustrations by Davidson $(1880,1881)$. While in a shell size, outline, sagittal profile of both valves and a dorsal valve interior the Algerian shells are distinctly similar to Lingulobolus hawkei, they completely lack a narrow longitudinal depression observed in both valves of the specimens assigned by Davidson (1880, p. 342) to Lingulobolus hawkei; therefore they are considered here as not conspecific. Lingulobolus sp. from the Ougarta Range readily differs from ?Lingulobolus brimonti (Rouault, 1850) from the Upper Armorican Sandstone Formation (Darriwilian) of France and Lingulobolus aff. brimonti (Rouault, 1850) described and illustrated by Legrand (1971) from the 
Darriwilian of Algerian Sahara in having a significantly less strongly biconvex shell with a subacuminate ventral valve and a gently ventral visceral area.

?Lingulobolus septatus Williams \& Curry, 1985, from Tourmakeady Limestone (Dapingian), Ireland has in the ventral valve a short median and two lateral septa in front of the pedicle groove unlike other species of Lingulobolus. It also lacks radial ornamentation on the external shell surface.

\section{Subfamily Glossellinae Cooper, 1956}

\section{Glossellininae gen. et sp. indet. 1}

Figure 4M

Material. - CUOR 118, dorsal internal mould; from locality PH137, Djebel Serraf Formation (Hirnantian) at vicinity of Ougarta Village.

Remarks. - This lingulide is known from a single very gently convex and strongly elongate dorsal valve lacking pseudointerarea and with a long dorsal median ridge extending anteriorly about two-thirds of sagittal valve length. The umbonal area shows a weakly impressed paired umbonal muscle scar, while other features of the shell internal morphology are not preserved. While attribution of the specimen to the subfamily Glossellininae is likely, its generic affiliation remains uncertain.

\section{Genus Libyaeglossa Havlíček, 1973 in Havlíček \& Massa (1973)}

Type species. - By original designation Libyaeglossa collombi Havlíček, 1973 in Havlíček \& Massa (1973).

\section{?Libyaeglossa sp.}

Figure 4K, L, N, O

Material. - Two exfoliated ventral valves, including CUOR 120 (Fig. 4K) and CUOR 121 (Fig. 4N); five exfoliated dorsal valves, including CUOR 119 (Fig. 4O), CUOR 122, CUOR 123, CUOR 124, CUOR 127 (Fig. 4L); all from locality PH237. One exfoliated ventral valve, CUOR 126 and two dorsal valves, including, one dorsal valve CUOR 125, from locality PH237-bis. Both localities are from Djebel Serraf Formation (Hirnantian) at vicinity of Ougarta Village.

Remarks. - This unnamed taxon is characterised by a subequally biconvex, subtriangular shell. The ventral valve is acuminate with a pointed umbo and a small subtriangular pseudointerarea bisected by a deep pedicle groove. The dorsal valve is thickened along the narrow posterior margin and is apparently lacking pseudointerarea.
The shell surface is smooth with faint growth lines and thin growth lamellae which appear close to the outer margins of large specimens. In these characters it shows distinct similarity to Libyaeglossa. The interior of both valves is weekly impressed and remains inadequately known both in the Algerian shells and Libyaeglossa collombi, therefore generic assignation of the former should be considered as provisional.

Externally, ?Libyaeglossa sp. shows some similarity to Rafanoglossa Havlíček, 1980, but it lacks a dorsal median ridge and most probably is not congeneric.

Superfamily Discinoidea Gray, 1840

Family Trematidae Schuchert, 1893

\section{Genus Orbiculothyris Wolfart, 1968 in Wolfart et al. (1968)}

Type species. - By original designation Orbiculothyris costellata Wolfart, 1968 in Wolfart et al. (1968).

Remarks. - While Orbiculothyris was initially assigned by Wolfart in Wolfart et al. (1968) to the Subfamily Orbiculoideinae, it was later considered by Holmer \& Popov (2000), as a junior synonym of Schizocrania Hall \& Whitfield, 1875. Indeed, characters of radial ornament and overall dorsal valve morphology of both genera are closely similar. The main difference of Orbiculothyris is a large elongate suboval pedicle foramen completely enclosed posteriorly. Though a broad, subtriangular pedicle opening open posteriorly at all growth stages is considered as diagnostic for the family Trematidae (Holmer \& Popov 2000), Bassett et al. (2009) demonstrated that at least in some species of Trematis the pedicle foramen can be sealed by the periostracal bands attached to the lateral sides of the notch, which were poorly mineralised and usually not fossilised. Attribution of Orbiculothyris to Trematiidae looks likely, while the most significant difference of this taxon from other genera of the family is the pedicle foramen completely enclosed posteriorly by the mineralised shell in later growth stages, which justifies its recognition as a separate genus. Also Orbiculothyris costellata is among the largest documented Ordovician discinoids.

Orbiculothyris ef. costellata Wolfart, 1968 in Wolfart et al. (1968)

Figure $5 \mathrm{~A}-\mathrm{C}, \mathrm{E}$

1973 Orbiculothyris costellata Wolfart. - Havlíček \& Massa, p. 280, pl. c, figs 3, 4, 10.

1977 Orbiculothyris costellata Wolfart. - Massa, Havlíček \& Bonnefous, p. 18, pl. 2, fig. 18.

? 2015 Schizocrania sp. - Colmenar \& Álvaro, figs 7f, 8g. 

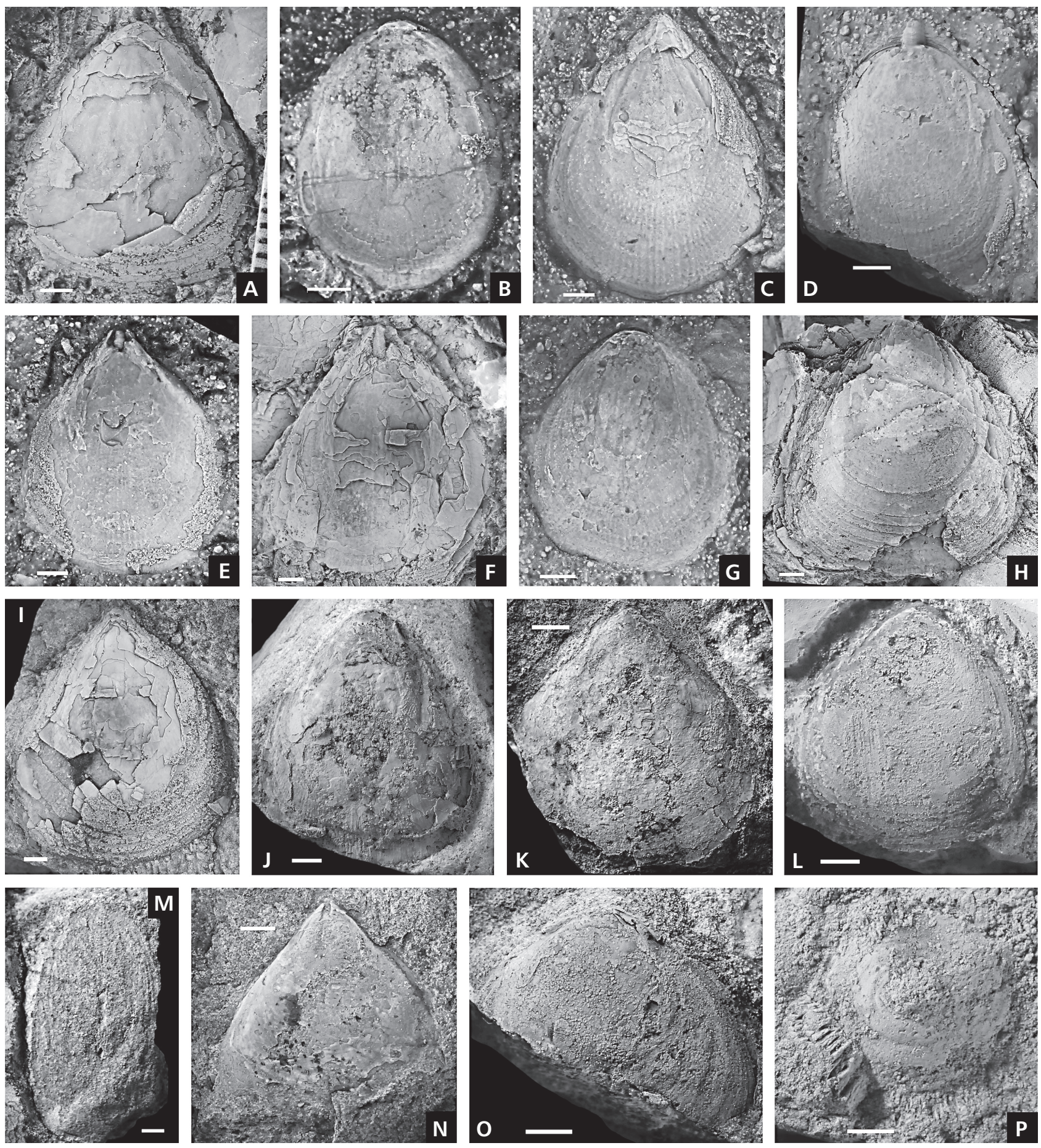

Figure 4. A-I - Lingulobolus sp., locality PH1821, Mesdar, Kheneg el Aatène Formation, Upper Member (Dapingian); A - CUOR109, exfoliated ventral valve exterior; B - CUOR 113, strongly exfoliated dorsal valve exterior showing crescentic pseudointerea; C - CUOR 111, ventral internal mould with partly preserved shell; D - CUOR 347, ventral internal mould of immature individual; E - CUOR 107, exfoliated ventral valve exterior; F - CUOR 114, strongly exfoliated ventral valve showing visceral area and mantle canals; G - CUOR 113, strongly exfoliated dorsal valve exterior; H - CUOR 100, ventral valve exterior; I - CUOR 102, exfoliated ventral valve exterior. • J - Lingulobolus septentrionalis Legrand, 1973, borehole UC 101, C43, 4170.50 m. Bordj Nili Sandstone Member (upper Furongian to lower Tremadocian), North Sahara, Algeria, UC101-C43 fr. $10 \mathrm{a}_{1}$, holotype, exfoliated ventral valve exterior. - K, L, N, O - ? Libyaeglossa sp., locality 237, vicinity of Ougarta Village, Djebel Serraf Formation (Hirnantian); K - CUOR 120, exfoliated ventral valve; L - CUOR 127, exfoliated dorsal valve; N - CUOR 121, exfoliated ventral valve; O - CUOR 119, exfoliated dorsal valve. $-\mathrm{M}$ - Glossellininae gen. et sp. indet. 1, locality PH137, vicinity of Ougarta Village, Djebel Serraf Formation (Hirnantian), CUOR 118, dorsal internal mould. • P - Mezotreta sp., locality PH1860, Kheneg et Tlaïa, Bou M'Haoud Formation Middle Member (?upper Sandbian-lower Katian), CUOR 136, exfoliated ventral valve. All scale bars are $2 \mathrm{~mm}$. 
Material. - One dorsal valve, CUOR 128 (Fig. 5A), from locality PH1807 at Foum El Kseib; six dorsal valves, including CUOR 129, CUOR 130 (Fig. 5B), CUOR 131, CUOR $132(\mathrm{Ld}=23.2, \mathrm{~W}=20.4, \mathrm{~T}=7.7$; Fig. 5C), CUOR 133, CUOR $134(\mathrm{Ld}=13.6, \mathrm{~W}=14.3, \mathrm{~T}=$ 2.1), from locality PH1860 at Kheneg et Tlaïa; and one dorsal valve, CUOR $135(\mathrm{Ld}=30.8, \mathrm{~W}=34.7, \mathrm{~T}=7.3$; Fig. 5E), from locality SY639 at Bou M'Haoud Ravine; all specimens are from Bou M'Haoud Formation (upper Sandbian-middle Katian).

Remarks. - Only dorsal valves are represented in the collection, therefore in species assignation of the Algerian shells we mainly follow Havlíček \& Massa (1973) who assigned similar shells from the Melez Chograne Formation of Fezzan, Libya to Orbiculothyris costellata; however, ventral valves in both cases remain unknown, thus their species assignation should be considered as provisional. The dorsal shell morphology of the shells from the Bou M'Haoud Formation is closely similar in having a moderately convex dorsal valve with a marginal umbo, and radial ornament of faint, dense, rounded costellae, while in the maximum shell width up to $34 \mathrm{~mm}$ they occupy intermediate position between Jordanian and Libyan shells. Specimens from the uppermost Lower Ktaoua and lower part of Upper Tiouririne formations illustrated by Colmenar \& Álvaro (2015) as Schizocrania sp. probably are also conspecific with the Algerian shells.

Order Siphonotretida Kuhn, 1949

Superfamily Siphonotretoidea Kutorga, 1848

Family Siphonotretidae Kutorga, 1848

\section{Genus Mezotreta Kutorga, 1848}

Type species. - By original designation Siphonotreta tentorium Kutorga, 1848.

\section{Mezotreta sp.}

Figure 4P

Material. - Exfoliated ventral valve, CUOR 136, from locality PH1860 at Kheneg et Tlaïa, Bou M'Haoud Formation, Middle Member (?upper Sandbian-lower Katian).

Remarks. - Mezotreta is extremely rare genus known exclusively from the ventral valves, yet it is a very distinctive taxon in having a conical shell with subcentrally placed umbo perforated by the pedicle foramen, which is unique in siphonotretides. While the type material was lost long time ago, the taxonomical position of Mezotreta was uncertain until re-discovery of a single ventral valve of Mezotreta tentorium Kutorga, 1848, in the Volkhov
Formation (Dapingian) of north-west Russia collected by Ivantsov. The specimen was illustrated by Holmer \& Popov (2000, fig. 79.2), who also confirmed its attribution to Siphonotretida. Another unnamed species questionably assigned by Popov et al. (2002) to Mezotreta is known from the Anderken Formation (upper Sandbian) of the Chu-Ili Range, Kazakhstan. The ventral valve from the Bou M'Haoud Formation is of a similar age and show similarity to the Kazakh shell in having concentric ornament of strong lamellae, but differs by an almost centrally placed umbo and strong, dense hallow spines. It represents probably a new yet unnamed species, but imperfect preservation does not permit its formal designation.

Class Strophomenata Williams, Carlson, Brunton, Holmer \& Popov, 1996

Order Strophomenida Öpik, 1934

Suborder Strophomenidina Öpik, 1934

Superfamily Strophomenoidea King, 1846

Subfamily Leptaeninae Hall \& Clarke, 1894

\section{Genus Leptaena Dalman, 1828.}

Type species. - Subsequent designation by King (1846) Leptaena rugosa Dalman, 1828.

\section{?Leptaena sp.}

Figure 6A

Material. - A single ventral internal mould, CUOR 137, from locality PH1780, Djebel Serraf Formation (Hirnantian) at El Kseib.

Remarks. - The specimen represents a transverse subrectangular ventral valve with a sharp dorsal geniculation accentuated by a strong rim, subangular in cross-section. The ventral interior has small teeth supported by short, widely divergent dental plates and an elongate, suboval muscle field surrounded laterally and anterolaterally by thin muscle bounding ridges. The specimen, probably, belongs to Leptaena, but in the absence of the dorsal valve its generic affiliation cannot be confirmed. This shell represents the first and only record on the occurrence of Leptaeninae in the Ordovician of the North African sector of Gondwana.

Order Orthida Schuchert \& Cooper, 1932

Suborder Orthidina Schuchert \& Cooper, 1932

Superfamily Orthoidea Woodward, 1852

Family Orthidae Woodward, 1852

\section{Genus Sivorthis Jaannusson \& Bassett, 1993}

Type species. - By original designation Sivorthis filistera Jaannusson \& Bassett, 1993. 

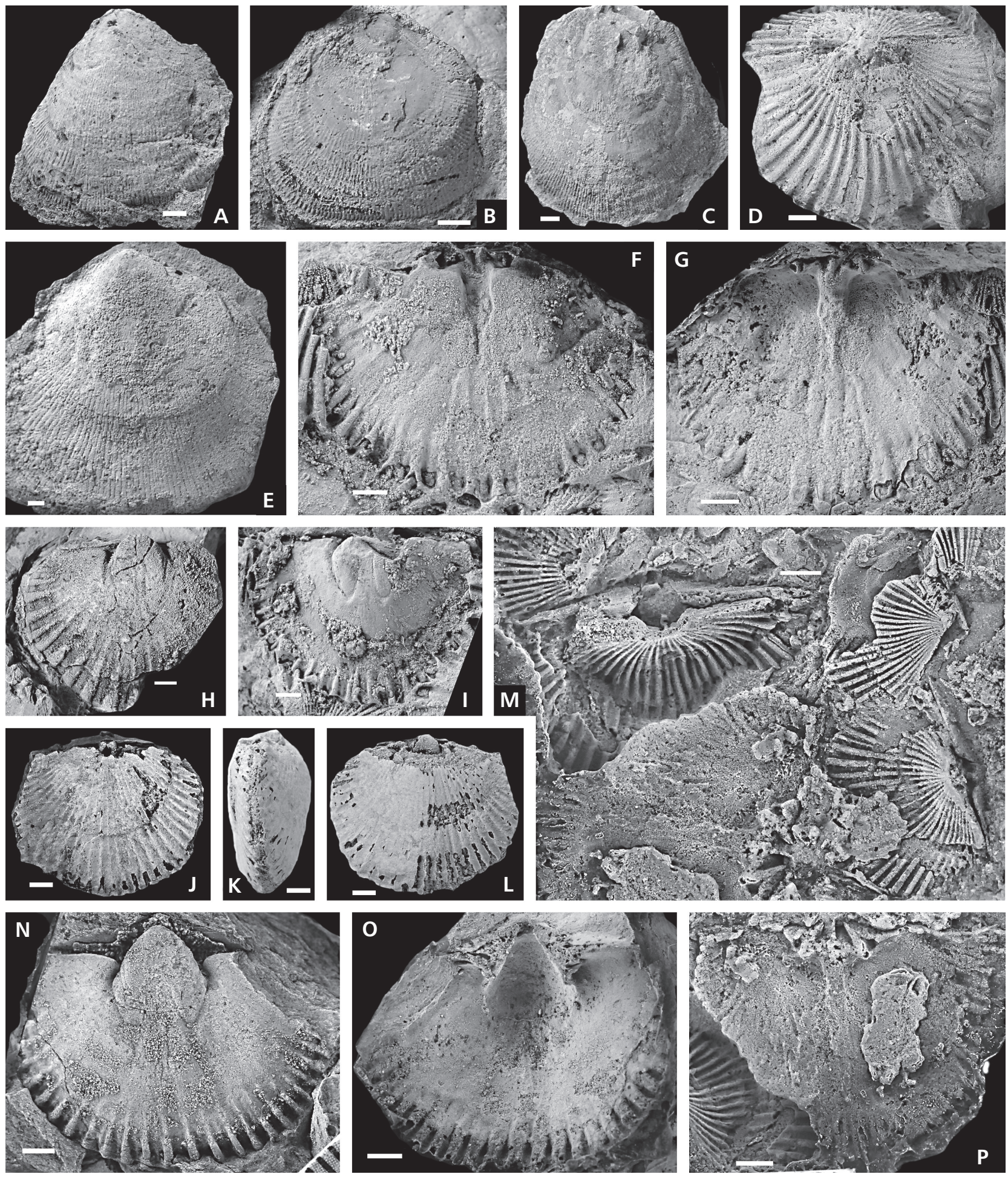

Figure 5. A-C, E - Orbiculothyris cf. costellata Wolfart, 1968 in Wolfart et al. (1968), Bou M'Haoud Formation (upper Sandbian-lower Katian); A - CUOR 128, dorsal valve, from locality PH1807 at Foum El Kseib; B - CUOR 130, dorsal valve; C - CUOR 132, dorsal valve, both from locality PH1860, Kheneg et Tlaïa; E - CUOR 135, latex cast of the dorsal exterior, from locality SY639 at Bou M'Haoud Village. • D, F-P - ?Sivorthis fraterna (Havlíček, 1971), Foum ez Zeidiya Formation, Lower Member (lower Darriwilian); D - CUOR 347, latex cast of partly disarticulated dorsal and ventral valves, locality PH350 at Feidj ez Zeidiya; F, G - CUOR 142, dorsal internal mould and latex cast of dorsal valve interior, locality PH1822 at Mesdar; H - CUOR 138, ventral internal mould, locality PH352 at Feidj ez Zeidiya; I - CUOR 143, ventral internal mould, locality PH1822 at Mesdar; J, K, L CUOR 350, articulated shell, dorsal, lateral and ventral views, locality PH350 at Feidj ez Zeidiya; M - latex cast of bedding surface showing a cluster of three dorsal valve exteriors with ventral interarea, locality PH1822 at Mesdar; N, O - CUOR 351, ventral internal mould and latex cast of ventral valve interior, locality PH351 at Feidj ez Zeidiya; P - CUOR 147, latex cast of dorsal valve interior, locality PH1822 at Mesdar. All scale bars are 2 mm. 
?Sivorthis fraterna (Havlíček, 1971)

Figure 5D, F-P

1971 Orthambonites fraternus Havlíček; p. 31, pl. 3, figs 7-10, pl. 23, fig. 3.

1983 Orthambonites cf. fraternus Havlíček. - Mergl, p. 340, pl. 1, fig. 17.

Holotype. - Ventral internal mould figured by Havlíček (1971, pl. 3, fig. 10), First Bani Group (Darriwilian), SidiTouhama, Morocco.

Material. - One articulated shell and two ventral valves preserved as internal and external moulds, including CUOR $350(\mathrm{Lv} \sim 14.8, \mathrm{Ld}=14.5, \mathrm{~W}=17.2, \mathrm{~T}=7.8$; Fig. $5 \mathrm{~J}-\mathrm{L})$, CUOR $348(\mathrm{~W}=23.0, \mathrm{Ml}=9.0, \mathrm{Mw}=5.3)$ and CUOR 349, from locality PH350 at Feidj ez Zeidiya. One ventral internal mould CUOR 351, from locality PH351 at Feidj ez Zeidiya. Three ventral and one dorsal valves, including: CUOR $138(\mathrm{Lv}=16.5, \mathrm{Ml}=6.8, \mathrm{Mw}=5.9$; Fig. 5H), CUOR 139, CUOR 140 and CUOR 141, from locality PH352 at Feidj ez Zeidiya. Four articulated shells, two ventral and three dorsal valves preserved as internal and external moulds, including CUOR $347(\mathrm{Lv}=15.5$, $\mathrm{W}=20.2, \mathrm{~T}=4.0$; Fig. 5D), CUOR 148, CUOR 149 (Fig. 5M), CUOR 143 (Fig. 5I), CUOR 144, CUOR 142 (Fig. 5F, G), CUOR 146, CUOR 147 (Fig. 5P); plus two fragments of ventral external moulds, one ventral internal mould and one dorsal external mould, from locality PH1822 at Mesdar. All specimens from Foum ez Zeidiya Formation (Darriwilian).

Description. - Shell ventribiconvex, about $77-86 \%$ as long as wide and about half as thick as long, with maximum length between posterior margin and mid-length. Hinge line slightly shorter than maximum shell width at the posterior one-third shell length. Cardinal extremities slightly obtuse. Anterior margin rectimarginate. Radial ornament with $26-30$ rounded ribs occasionally bifurcating in the umbonal area and separated by interspaces of equal width. Concentric ornament of fine crowded fila.

Ventral valve lateral profile moderately convex with maximum height at about one-third valve length from the umbo. Ventral interarea moderately high, apsacline, very gently curved in cross section with open triangular delthyrium (Fig. 5O). Dorsal valve very gently and evenly convex with low, anacline interarea divided by a narrow, open notothyrium.

Ventral valve with strong teeth supported by the short, divergent dental plates. Ventral muscle field gently impressed, subcordate extending slightly beyond the delthyrial cavity floor, bounded anterolaterally by low muscle bounding ridges, about $40 \%$ as long as the valve (Fig. $5 \mathrm{~N}, \mathrm{O}$ ). Ventral adductor scars narrow, slightly short- er then diductor scars and separated from them by low ridges (Fig. 5H, I). Umbonal area occupied by a short, gently impressed pedicle callist.

Dorsal valve interior with a simple, ridge-like cardinal process bisecting a narrow, posteriorly inclined notothyrial platform. Brachiophores short, tabular with slightly thickened bases (Fig. 5P). Sockets deep, subtriangular, lacking fulcral plates. Dorsal adductor muscle scars weakly impressed with a larger posterior pair, bisected posteriorly by a low, thick median ridge, becoming faint and thin in front of posterior adductor scars and terminated slightly anterior to the valve mid-length. Dorsal mantle canals weakly impressed, probably digitate.

Remarks. - Originally, this species was assigned to Orthambonites together with another Moroccan species Orthambonites tilfetensis Havlíček, 1971. The latter taxon was subsequently reassigned to Shoshonorthis by Jaanusson \& Bassett (1993) in their comprehensive revision of Orthambonites and related brachiopod genera; however, taxonomical position of Orthambonites fraternus was not discussed by these authors. Nevertheless, it was not included neither in the list of species assigned to Orthambonites, nor to Paralenorthis or any other genus newly designated in the cited publication.

The specimens in our collection are most probably conspecific with the shell from the Foum ez Zeidiya Formation of Jebel Heche illustrated by Mergl (1983) as Orthambonites cf. fraternus. Also they have no significant differences in the characters of surface ornament and internal shell morphology from the types described and illustrated by Havlíček (1971) and they are considered here within the same taxon. In the original description of the species given by Havlíček (1971, p. 31) occasional presence of fine radial capillae was reported. According to the cited publication these capillae can be observed only exceptionally, although there is no sign of radial capillae on the best preserved specimen illustrated by Havlíček (1971, pl. 3, fig. 7). The specimens from our collection lack radial capillae, while dense concentric fila are characteristic. Algerian shells are also characterised by a subcordate ventral muscle field extending somewhat beyond the delthyrial cavity floor, tabular brachiophores and weakly costellate radial ornament. These features are not characteristic for Orthambonites or Paralenorthis, but reported for Sivorthis (Jaanusson \& Bassett 1993, Williams \& Harper 2000). Therefore they are provisionally assigned to that genus; however, the lack of evidence of radial capillae makes this generic assignment tentative.

Suborder Dalmanellidina Moore, 1952

Superfamily Dalmanelloidea Schuchert, 1913

Family Heterorthidae Schuchert \& Cooper, 1931 

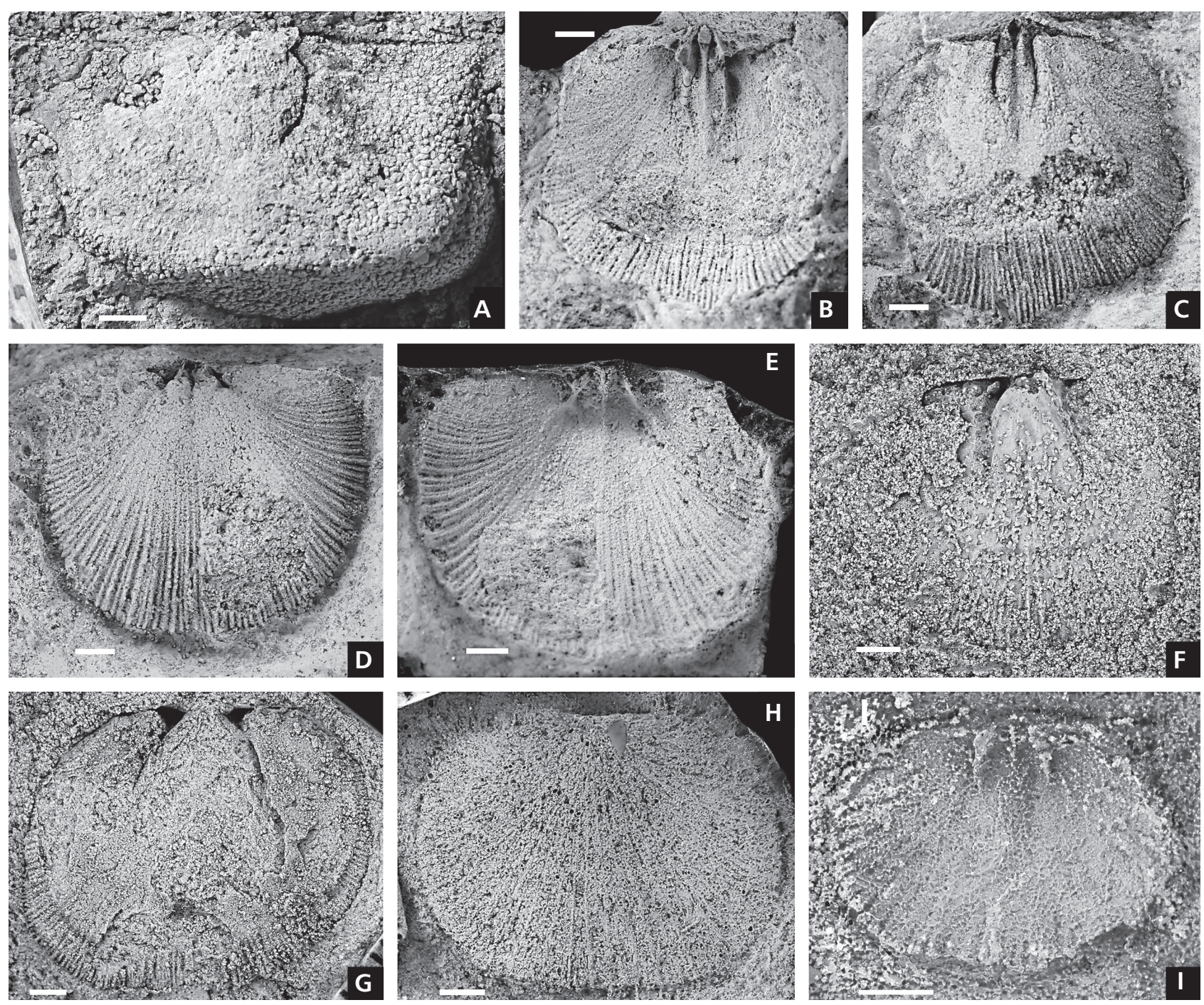

Figure 6. A - ?Leptaena sp., from locality PH1780, Djebel Serraf Formation (Hirnantian) at E1 Kseib, CUOR 137, ventral internal mould. • B, C Drabovinella regia Havlíček, 1971, locality 1775, Bou M'Haoud Formation, isolated outcrop at northern limb of Bou M'Haoud syncline, CUOR 272, latex cast of dorsal interior, dorsal internal mould. - D-H - Svobodaina cf. havliceki Villas, 1985, from locality PH468, Bou M'Haoud Formation, Upper Member (middle Katian) at vicinity of Bou M'Haoud Village; D, E - CUOR 150, dorsal internal mould and latex cast of interior; F - CUOR 152, ventral internal mould; G - CUOR 153, ventral internal mould; H - CUOR 154, latex cast of ventral exterior. - I - Drabovia cf. tenuiseptata Havlíček, 1971, from locality PH1834, Bou M’Haoud Formation, Lower Member (upper Sandbian-lower Katian) at Kheneg at Tlaïa; CUOR 215, latex cast of dorsal valve interior. All scale bars are $2 \mathrm{~mm}$.

\section{Genus Fehamya Mergl, 1983}

[= Fehamaya Harper 2007, p. 2692 (incorrect subsequent spelling)]

Type species. - By original designation Fehamya circula Mergl, 1983.

\section{?Fehamya sp.}

Figure $7 \mathrm{~V}, \mathrm{~W}$

Material. - Ventral internal mould, CUOR 351, and dorsal internal mould, CUOR 352, from locality PH1802 at
Height 472 m, Bou M'Haoud Formation, Lower Member (?upper Sandbian-lower Katian).

Remarks. - The only species presently assigned to the genus is Fehamya circula Mergl, 1983 documented from a single locality at Foum el Fehamya in Morocco dated as the 'upper Ashgill'. The Algerian shells are provisionally assigned to Fehamya, because they have a gently impressed, flabellate ventral muscle field with diductor scars completely enclosing a shorter adductor scar, dorsal cardinalia with a ponderose cardinal process and short, widely divergent brachiophores, and a long dorsal median 
ridge bisecting a weakly impressed dorsal adductor scars. Details of the cardinal process, vascula terminalia in the posterior part of the shell and radial ornament are not observed, therefore generic assignation of the specimens is tentative while their species affiliation is also uncertain because of restricted material available for study.

\section{Genus Svobodaina Havlíček, 1951}

Type species. - By original designation Orthis ellipsoides Barrande, 1848.

\section{Svobodaina cf. havliceki Villas, 1985}

Figure 6D-H

Material. - Four ventral valves, including: CUOR 154 $(\mathrm{Lv}=15.2, \mathrm{~W}=18.4, \mathrm{Iw}=16.5$; Fig. $6 \mathrm{H}), \mathrm{CUOR} 152$ (Fig. 6F), CUOR $153(\mathrm{Lv}=19.8, \mathrm{~W}=23.9, \mathrm{Iw}=14.2, \mathrm{Ml}$ $=9.8, \mathrm{Mw}=8.5$; Fig. $6 \mathrm{G}$ ), CUOR 353, and three dorsal valves, including: CUOR $150(\mathrm{Ld}=15.2, \mathrm{~W}=17.5, \mathrm{Iw}$ $=16.5$; Fig. $6 \mathrm{D}, \mathrm{E})$, CUOR $151(\mathrm{Ld}=18.3, \mathrm{~W}=20.8$, $\mathrm{Iw}=16.7$ ), CUOR 155 , mostly preserved as internal and external moulds; from locality PH468 at vicinity of Bou M'Haoud Village, Bou M'Haoud Formation, Upper Member (middle Katian).

Remarks. - Svobodaina cf. havliceki is represented in the collection by a small number of shells preserved as external and internal moulds in a coarse clastic sediment. Yet their provisional assignation to the species is likely, because they show a characteristic slightly transverse, suboval, strongly dorsibiconvex shell with a shallow dorsal umbonal sulcus fading anteriorly, finely multicostellate radial ornament, a large, flabellate ventral muscle field, dorsal cardinalia with a strong ovoid, posteriorly bilobed cardinal process on a ridge-like shaft, and simple bladelike divergent brachiophores; however, listed characters of the dorsal interior in the Algerian shells are less robust, than in the types described by Villas (1985). Detailed discussion of Svobodaina havliceki and its affinity to related species was given by Colmenar et al. $(2013,2014)$.

\section{Genus Tafilaltia Havlíček, 1970}

Type species. - By original designation Tafilaltia occidentalis Havlíček, 1970.

\section{Tafilaltia destombesi Havlíček, 1970}

Figure $7 \mathrm{~L}, \mathrm{~N}-\mathrm{T}$

1970 Tafilaltia destombesi sp. nov.; Havlíček, p. 19, pl. 3, figs $1-8$, pl. 10, fig. 8 .

1971 Tafilaltia destombesi Havlíček. - Havlíček, p. 51, pl. 9, figs 1-9.

2015 Tafilaltia destombesi Havlíček. - Colmenar \& Álvaro, fig. 6a-f.

Holotype. - Ventral internal mould illustrated by Havlíček (1970, pl. 3, fig. 8), Lower Ktaoua Formation (?upper Sandbian-lower Katian), Jebel Douifa, Massif Tadout, Morocco.

Material. - Two ventral valves, including CUOR 159, CUOR 160, and five dorsal valves, including CUOR 156, CUOR 354, CUOR 157 (Fig. 6P, T), CUOR 158, CUOR 161, preserved as internal and external moulds, from locality PH1836 at Kheneg et Tlaïa. One ventral valve CUOR 167, (Fig. 7N, O), and seven dorsal valves, including CUOR 166 (Fig. 7L), CUOR $163(\mathrm{Ld}=9.1, \mathrm{~W}=$ 12.6, Iw $=12.2$ ), CUOR 164, CUOR 165, CUOR 168 (Fig. 7Q, R), CUOR 169, CUOR 170 (Fig. 7S), preserved as internal and external moulds, from locality at Kheneg et Tlaïa. Total three ventral and 13 dorsal valves, from Bou M'Haoud Formation Middle Member (?upper Sandbianlower Katian).

Remarks. - The Algerian shells show a convex dorsal valve, strongly impressed ventral and dorsal muscle fields,

Figure 7. A-K, M, Tissintia convergens Havlíček, 1970, upper part of Foum ez Zeidiya Formation (upper Darriwilian); A, B - CUOR 177, latex cast of dorsal valve interior, dorsal internal mould, sample PH1791 at Zmeïlet el Barka; C - CUOR 180, latex cast of dorsal valve interior, locality PH1791 at Zmeïlet el Barka; D - CUOR 181, latex cast of dorsal valve interior, locality PH1791 at Zmeïlet el Barka; E - CUOR 182, latex cast of dorsal valve exterior, locality PH1791 at Zmeïlet el Barka; F - CUOR 185, latex cast of ventral valve exterior, locality PH1791 at Zmeïlet el Barka; G - CUOR 190, latex cast of dorsal valve exterior, locality PH1852 at Kheneg el Aatène; H - CUOR 171, latex cast of ventral valve interior, locality PH1791 at Zmeïlet el Barka; I, J - CUOR 175, ventral internal mould, latex cast of ventral interior, locality PH1791 at Zmeïlet el Barka; K - CUOR 204, ventral internal mould, from locality PH1854 at Kheneg et Tlaïa; M - CUOR 184, latex cast of dorsal exterior, locality PH1829 at Bou M'Haoud Ravine. • L, N-T - Tafilaltia destombesi Havlíček, 1971, Bou M’Haoud Formation Middle Member (upper Sandbian-lower Katian) at Kheneg et Tlaïa; L - CUOR 166, latex cast of dorsal valve exterior, locality PH1860; N, O - CUOR 167, ventral internal mould and latex cast of ventral valve interior, locality PH1860; P, T - CUOR 157, dorsal internal mould, latex cast of dorsal valve interior, locality PH1836; Q, R - CUOR 168, dorsal internal mould, latex cast of dorsal valve interior, locality PH1860; S - CUOR 170, dorsal internal mould, locality PH1860. • U - ?Hirnantia sp. 1, from locality PH1797, Bou M'Haoud Formation, Lower Member (upper Sandbian-lower Katian) at Daïet en Nouguir; CUOR 298, ventral internal mould. • V, W - ?Fehamya sp., from locality PH1802, Bou M'Haoud Formation, Lower Member (upper Sandbian-lower Katian), height 472 m; V - CUOR 352, dorsal internal mould; W - CUOR 351, ventral internal mould. All scale bars are $2 \mathrm{~mm}$. 

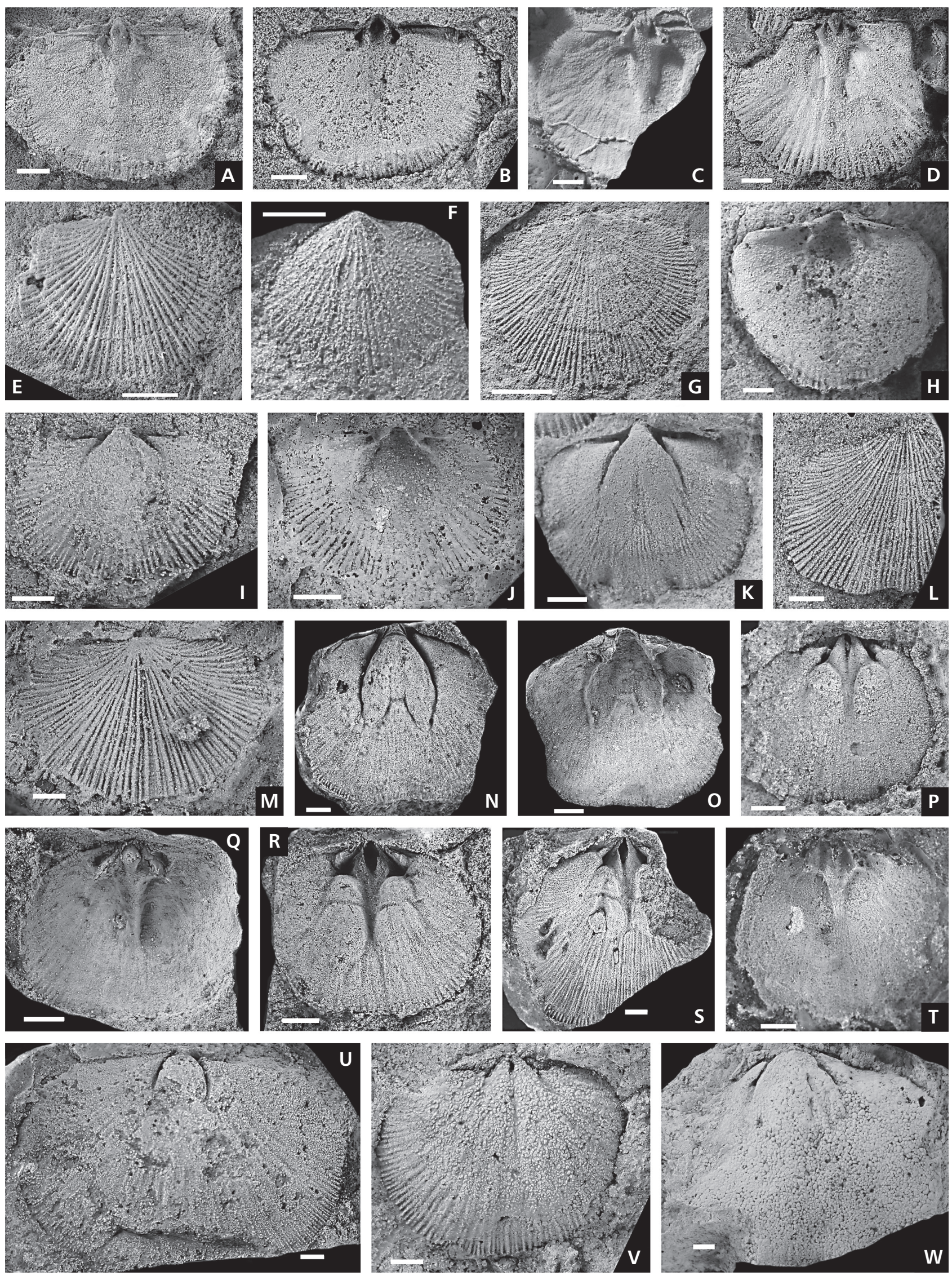
a robust cardinal process with an indistinctly trilobed posterior face occluding the narrow notothyrial chamber, and delicate anteriorly divergent brachiophores considered by Havlíček (1970) as indicative for Tafilaltia destombesi. Detailed description and discussion of affinities of the species is given in the cited publication.

\section{Genus Tissintia Havlíček, 1970}

Type species. - By original designation Tissintia convergens Havlíček, 1970.

\section{Tissintia convergens Havlíček, 1970}

Figure 7A-K, M

1970 Tissintia convergens sp. nov.; Havlíček, p. 15, pl. 1, figs 1-6.

1971 Tissintia convergens Havlíček. - Havlíček, p. 51, pl. 8 , figs $1-7$.

Holotype. - Dorsal internal mould illustrated by Havlíček (1970, pl. 1, fig. 1), Tadrist Formation (Darriwilian), locality 1591 west of Foum Zguid, Morocco.

Material. - Six ventral valves, including CUOR 171 (Lv $=11.2, \mathrm{~W}=13.6, \mathrm{Iw}=12.0$; Fig. 7H), CUOR 172, CUOR 173, CUOR 174, CUOR $175(\mathrm{Lv}=7.7, \mathrm{~W}=11.8, \mathrm{Ml}=$ 4.1; Fig. 7I, J), CUOR 176, and six dorsal valves, including CUOR $177(\mathrm{Ld}=9.4, \mathrm{~W}=12.3, \mathrm{Iw}=11,2, \mathrm{Sl}=5.4$; Fig. 7A, B), CUOR 178, CUOR 179, CUOR 180 (Fig. 7C, L); CUOR $181(\mathrm{Ld}=10.0, \mathrm{Sl}=6.0$; Fig. 7D $)$, CUOR 182 (Fig. 7E), preserved mainly as external and internal moulds, from Locality PH1791 at Zmeïlet el Barka. Two dorsal internal moulds and three dorsal external moulds from locality PH1828 at Kheneg el Aatène. Dorsal external mould, CUOR 184 (Fig. 7M), from locality PH1829 at Bou M'Haoud Ravine. Four ventral valves, including: CUOR 185 (Fig. 7F), CUOR 188, CUOR 189, CUOR 192, and six dorsal valves, including CUOR $190(\mathrm{Ld}=9.7, \mathrm{~W}=$ 11.6, Iw = 10.9; Fig. 7G), CUOR 191, CUOR 193, CUOR 194, preserved as internal and external moulds from locality PH1852 at Kheneg el Aatène. Four ventral valves, including: CUOR 195, CUOR 196, CUOR 197, CUOR $204(\mathrm{Lv}=10.0 . \mathrm{W}=11.9, \mathrm{Iw}=10.0, \mathrm{Ml}=5.3, \mathrm{Mw}=$ 5.2; Fig. 7K), and six dorsal valves, including CUOR 202, CUOR 203, CUOR 198, CUOR 199, CUOR 200, CUOR 201, mostly preserved as internal and external moulds from locality PH1854 at Kheneg et Tlaïa. Three ventral valves, including CUOR $205(\mathrm{Lv}=7.0, \mathrm{~W}=7.8)$, and five dorsal valves, including CUOR $206(\mathrm{Lv}=6.9, \mathrm{~W}=7.3$, $\mathrm{Iw}=6.4)$, preserved as internal and external moulds from locality SY499 at Foum opposite Daïet en Nouguir. Total 19 ventral and 28 dorsal valves, all specimens are from Foum ez Zeidiya Formation (upper Darriwilian).
Remarks. - Havlíček (1970) gave a detailed description of the species; however, illustrations of the ventral valve interior shown on rock slabs cannot be considered as adequate. He also documented the occurrence of Tissintia convergens at Feidj ez Zeidiya in the Ougarta Range (Havlíček 1971; locality 2011). The specimens from that locality were not illustrated, but they most likely derived from the upper part of the Foum ez Zeidiya Formation. Indeed, Algerian shells have no significant differences from Moroccan representatives of the taxon in characters of cardinalia, a narrow notothyrial platform occluded by the strong, bilobed cardinal process (Fig. 7C, D, L). Small brachiophores are convergent to the valve floor and supported by short subparallel ridges, with posterior edges touching inner sides of dorsal posterior adductor scars (Fig. 7A, L), and a gently impressed, flabellate ventral muscle field with indistinct adductor scars (Fig. 7K), extending beyond the mid-valve, are also very similar. The main differences between Moroccan and Algerian populations of Tissintia are in smaller sizes and finer radial ornament (7-10 ribs per $2 \mathrm{~mm}$ anteromedially) of the Algerian shells. Yet, they most probably belong to the same taxon.

Superfamily Enteletoidea Waagen, 1884

Subfamily Drabovidae Havlíček, 1951

\section{Genus Drabovia Havlíček, 1951}

Type species. - By original designation Orthis redux Barrande, 1848.

\section{Drabovia cf. tenuiseptata Havlíček, 1971}

Figures 6I; 8A-D, Q, T

$$
\begin{aligned}
& \text { cf. } 1971 \text { Drabovia tenuiseptata; Havlíček, p. 54, pl. 14, figs } \\
& \text { 7-9. } \\
& 1983 \text { Drabovia tenuiseptata Havlíček, 1971. - Mergl, p. 345, } \\
& \text { pl. 3, figs 6, } 9 \text {. }
\end{aligned}
$$

Material. - Three ventral valves, including CUOR 207 (Fig. 8A), CUOR 208, CUOR 209, from locality PH1802, Height $472 \mathrm{~m}$. Six ventral valves preserved as internal and external moulds, including CUOR 210, CUOR 211 (Fig. 8C), CUOR 212 (Fig. 8D), CUOR 213, CUOR 214 (Fig. 8B), CUOR 215 (Fig. 6I), from locality PH1834 at Kheneg at Tlaïa. One dorsal internal mould, from locality PH1836 at Kheneg at Tlaïa. Specimen CUOR 364 (Fig. $8 Q$ ), oneventral external mould, from locality PH1855 at Kheneg et Tlaïa. Internal and external moulds of dorsal valve, CUOR 216, CUOR216bis, from locality PH1856 at Kheneg et Tlaïa. Total ten ventral and two dorsal valves; all from Bou M'Haoud Formation, Lower to Middle members (upper Sandbian-lower Katian). 

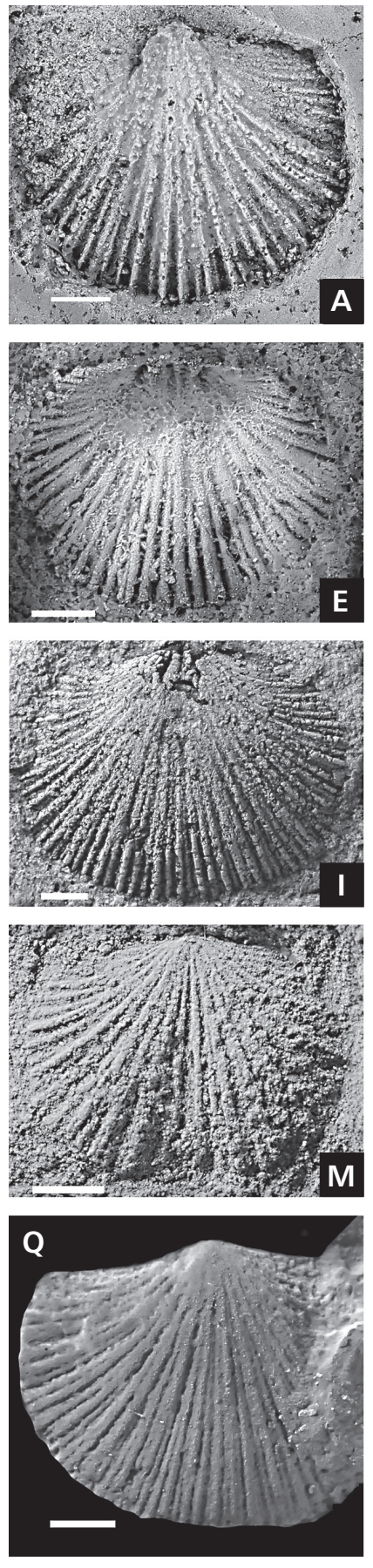
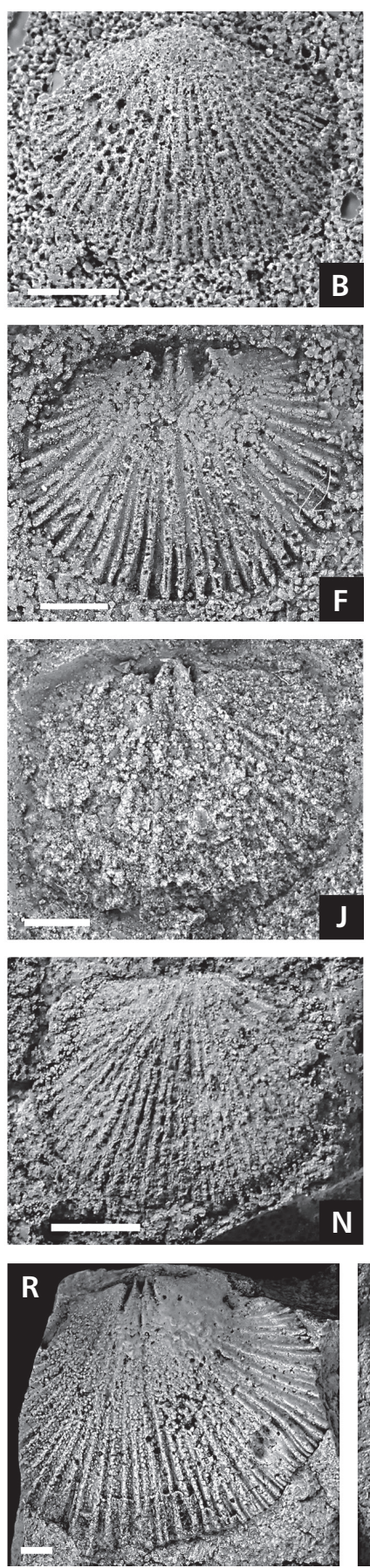
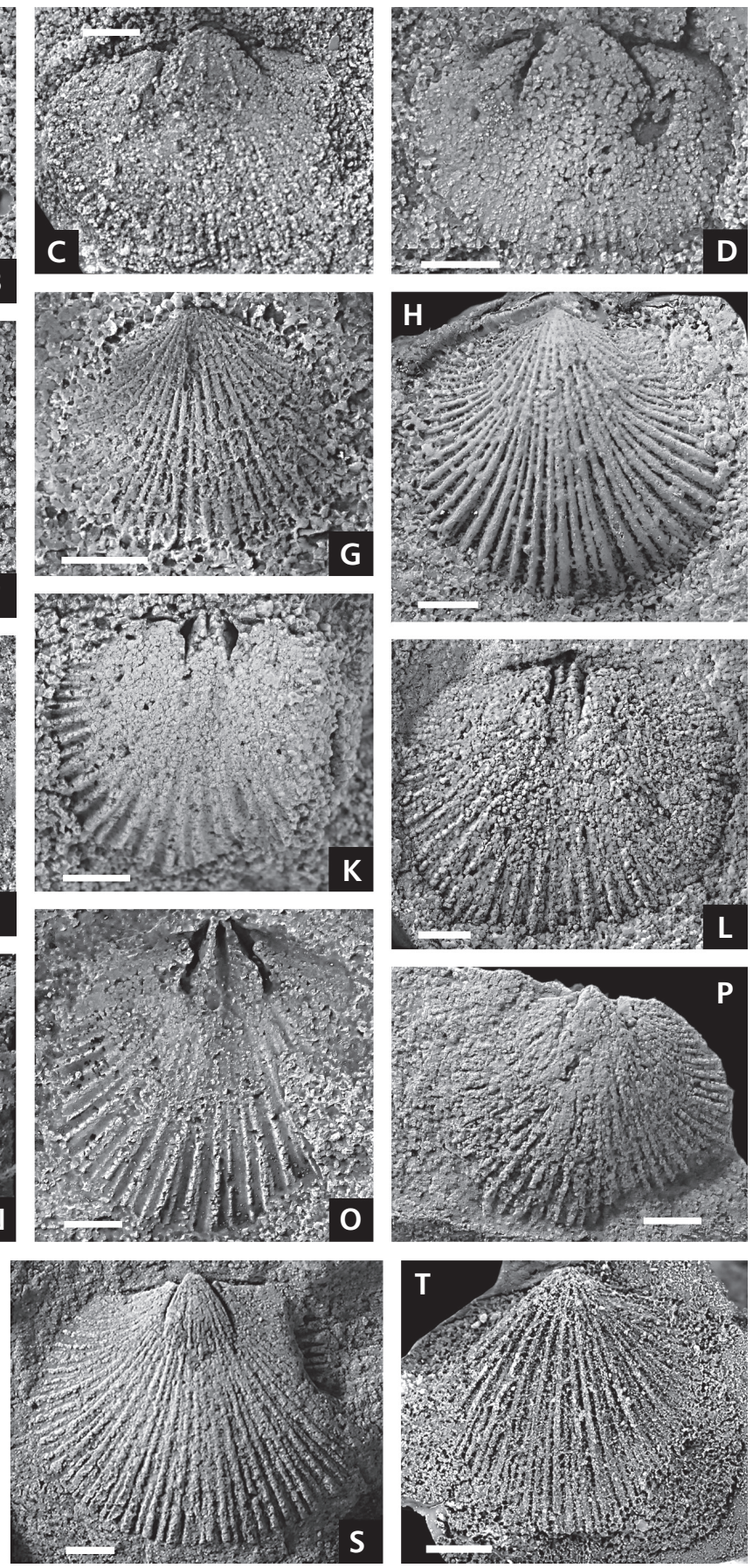

Figure 8. A-D, Q, T - Drabovia cf. tenuiseptata Havlíček, 1971, from Bou M'Haoud Formation (upper Sandbian-lower Katian); A - CUOR 207, ventral internal mould, from locality PH1802, height $472 \mathrm{~m}$; B - CUOR 214, latex cast of ventral valve exterior, from locality PH1834, at Kheneg et Tlaïa; C - CUOR 210, ventral internal mould, from locality PH1834 at Kheneg et Tlaïa; D - CUOR 211, ventral internal mould, from locality PH1834 at Kheneg et Tlaïa; Q - CUOR 212, latex cast of ventral valve exterior, from locality PH1855 at Kheneg et Tlaïa; T - CUOR 211, latex cast of ventral valve exterior, from locality PH1834 at Kheneg et Tlaïa. • E-H, I-P, R, S - Drabovia sp., Bou M'Haoud Formation, Upper Member (middle Katian) at Bou M'Haoud; E, F - CUOR 242, latex cast of dorsal valve interior and dorsal internal mould, from locality SY636bis; G - CUOR 241, latex cast of ventral exterior, from locality SY636bis; H - CUOR 240, latex cast of ventral exterior from locality SY636bis; I - CUOR 234, dorsal internal mould, from locality PH467; J - CUOR 220, dorsal internal mould, from locality PH465; K - CUOR 229, dorsal internal mould, from locality PH466; L - CUOR 227, dorsal internal mould, from locality PH466; M - CUOR 217, dorsal valve exterior, from locality PH464; N - CUOR 244, dorsal valve exterior, from locality SY639; O - CUOR 232, dorsal internal mould, from locality PH467; P - CUOR 248, ventral internal mould, from locality SY640; R - CUOR 226, dorsal internal mould, from locality PH466; S - CUOR 245, ventral internal mould, from locality SY640. All scale bars are $2 \mathrm{~mm}$. 
Remarks. - The occurrence of Drabovia tenuiseptata in the Upper Ordovician of the Ougarta Range was first documented by Mergl (1983), who figured two specimens representing dorsal and ventral internal moulds; however, their taxonomical attribution was not supported by a description or discussion. These specimens closely resemble the shells from the Bou M'Haoud Formation Lower Member in our collection and they are most probably conspecific. While characters of the ventral muscle field and dorsal cardinalia in the Algerian shells have no significant differences from Moroccan Drabovia tenuiseptata as described and illustrated by Havlíček (1971), preservation of dorsal valves available for study is inadequate to observe details of dorsal valve radial ornamentation, including characters of branching in the medial sectors I to III. Therefore taxonomical assignation of the shells from the Ougarta Range to Drabovia tenuiseptata is considered here as tentative.

\section{Drabovia sp.}

Figure $8 \mathrm{E}-\mathrm{H}, \mathrm{J}-\mathrm{P}, \mathrm{R}, \mathrm{S}$

1983 Drabovia sp. - Mergl, p. 345, pl. 3, figs 4, 5, 7, 8.

Material. Three dorsal valves, including CUOR 217 (Fig. 8M), CUOR 218, CUOR 219; from locality PH464. One dorsal internal mould, CUOR $220(\mathrm{Ld}=8.8, \mathrm{~W} \sim 10.5$; Fig. 8J), from locality PH465bis. One ventral internal mould, CUOR 256, and ten dorsal valves preserved as internal and external moulds, including: CUOR 221, CUOR 222, CUOR 223, CUOR 224, CUOR 226 (Fig. $8 \mathrm{R})$; CUOR $227(\mathrm{Ld}=17.5, \mathrm{~W}=20.8, \mathrm{~T}=3.2$; Fig. $8 \mathrm{~L})$, CUOR 228, CUOR 229 (Fig. 8K), CUOR 230, CUOR 231, from locality PH466. Four dorsal internal moulds, including CUOR 232 (Fig. 8O), CUOR 233, CUOR 234 $(\mathrm{Ld}=11.7, \mathrm{~W}=14.7, \mathrm{Iw}=9.9$; Fig. 8I), CUOR 235, from locality PH467. Two ventral internal moulds, including CUOR 236 and CUOR 237, from locality PH468; ventral internal mould, CUOR 238, and dorsal internal mould; from locality SY636. Four ventral and four dorsal internal moulds, from locality PH1841. Two ventral external moulds, including CUOR 240 (Fig. 8H) and CUOR 241 (Fig. 8G), from locality SY636bis. Three dorsal valves, including CUOR 242 (Fig. 8E, F); CUOR 243 and CUOR 244 (Fig. 8N), from locality SY639. Three ventral internal and external moulds, including CUOR $245(\mathrm{Lv}=12.8, \mathrm{~W}$ $=16.7, \mathrm{Ml}=5.3, \mathrm{Mw}=4.3$; Fig. $8 \mathrm{~S}$ ), CUOR 247, CUOR $248(\mathrm{Lv}=9.2, \mathrm{~W}=11.6$; Fig. $8 \mathrm{P})$; and one dorsal internal mould, CUOR 246, from sample SY640. All from Bou M'Haoud Formation, Upper Member (Katian) at the area of Bou M'Haoud Village; total 13 ventral and 26 dorsal valves.

Remarks. - Disarticulated valves of Drabovia sp. are relatively common in the Bou M'Haoud Formation Upper
Member. It recalls Drabovia pentagonomya Havlíček, 1971, from the Lower Ktaoua Formation of Anti-Atlas, Morocco in a general shape and proportions of both valves, finely fascicostellate radial ornament with ribs varying in a number from 4 to 8 per $2 \mathrm{~mm}$ at the posterior margin of mature individuals and in characters of cardinalia; however, they do not rich the maximum size of Drabovia pentagonomya and have a narrower ventral muscle field. Unlike Drabovia pentagonomya, brachiophore supports in most of the observed specimens from the upper member of Bou M'Haoud Formation are only slightly anteriorly divergent to almost parallel (Fig. 8F, J, K), though specimens with widely divergent brachiophores supports characteristic of Drabovia pentagonomya are present in small numbers within the same populations (Fig. 8I, O). Algerian shells may represent a separate taxon closely related Drabovia pentagonomya, or a local morphologically variable population of the latter species; however, it would be difficult to make their precise taxonomic discrimination from the available material.

The shells of Drabovia sp. figured and briefly discussed by Mergl (1983) co-occur with Drabovinella maxima, therefore they were sampled most probably from the upper member of the Bou M'Haoud Formation. The ventral and dorsal internal moulds illustrated in the cited publication are closely comparable with specimens of Drabovia sp. in our collection and are considered here as conspecific.

\section{Genus Drabovinella Havlíček, 1951}

Type species. - By original designation Orthis draboviensis Barrande, 1879.

\section{Drabovinella maxima Mergl, 1983}

Figure 10A, B, D-H

1983 Drabovinella maxima sp. nov.; Mergl, p. 342, pl. 2, figs 1-8.

Holotype. - VH 4001a, dorsal valve, Bou M'Haoud Formation, Upper Member (middle Katian), Bou M'Haoud, Ougarta, Algeria.

Material. - Six ventral valves, including CUOR 225, CUOR 250a (Fig. 10A), CUOR $251(\mathrm{Lv}=16.1, \mathrm{Ml}=7.5$, $\mathrm{Mw}=5.2$; Fig. 10B $)$, CUOR $253(\mathrm{Lv}=31.1, \mathrm{Ml}=13.2$, $\mathrm{Mw}=7.4)$, CUOR $360(\mathrm{Lv}=16.0, \mathrm{~W}=18.3, \mathrm{Ml}=5.5$, $\mathrm{Mw}=3.4$ ), CUOR 256, and four dorsal valves, including CUOR $249(\mathrm{Ld}=24.2, \mathrm{~W}=32.3, \mathrm{Sl}=11.0, \mathrm{BBw}=5.9)$, CUOR 252, CUOR $253(\mathrm{Ld}=26.2, \mathrm{~W}=31.2, \mathrm{Iw}=22.3$, $\mathrm{Sl}=12.2, \mathrm{BBw}=9.8), \mathrm{CUOR} 255(\mathrm{Ld}=18.2, \mathrm{~W}>21.4$, $\mathrm{BBl}=4.2$ ), preserved as internal and external moulds, from locality PH466. Ventral internal mould, CUOR 257, (Lv = $36.0, \mathrm{~W}=37.1, \mathrm{Iw}=22.4, \mathrm{Ml}=18.0, \mathrm{Mw}=10.2$, from 

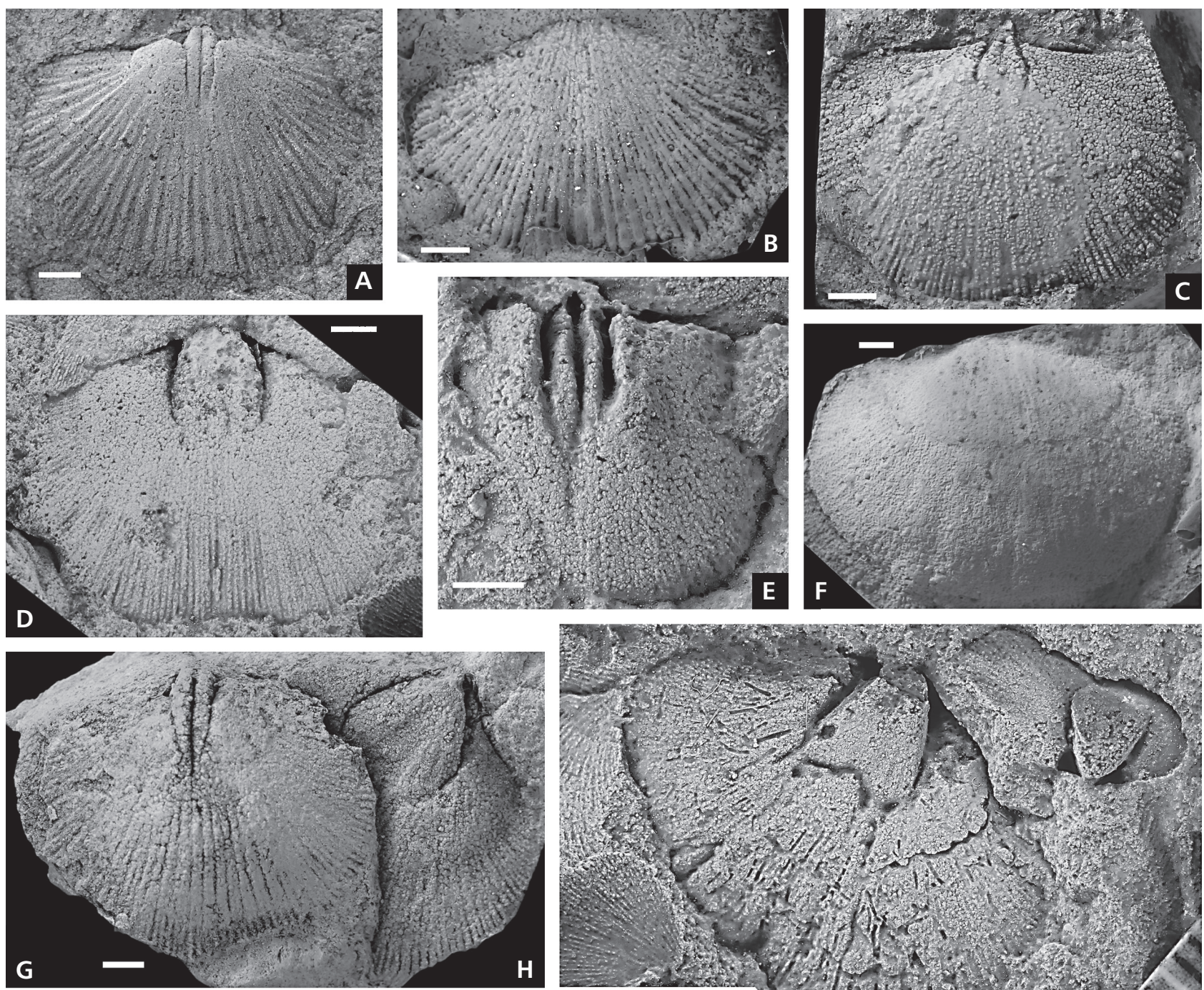

E
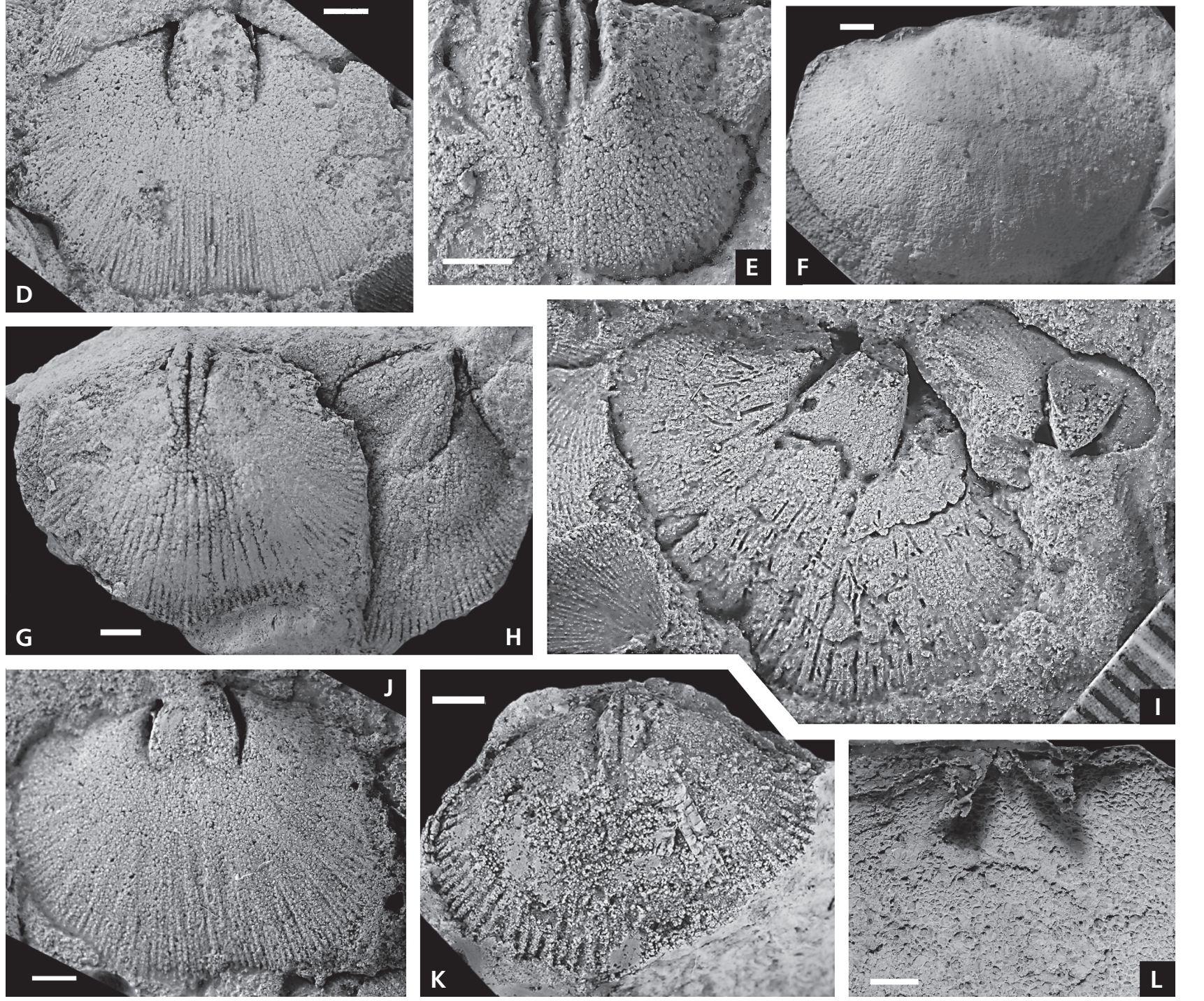

Figure 9. A, B, D, E, G-K - Drabovinella regia Havlíček, 1971, Bou M’Haoud Formation, Lower Member (upper Sandbian-lower Katian); A - CUOR 284, dorsal internal mould from locality SY644 at Foum at Tinneslem; B - CUOR 282, latex cast of dorsal exterior, from locality PH1801, height 472 m; D - CUOR 277, ventral internal mould, from locality PH1775 at Bou M'Haoud; E - CUOR 275, dorsal internal mould, from locality PH1775 at Bou M'Haoud; G - CUOR 273, dorsal internal mould, from locality PH1775 at Bou M'Haoud; H - CUOR274, ventral internal mould, from locality PH1775 at Bou M'Haoud; I - CUOR 278, ventral internal mould, from locality PH1775 at Bou M'Haoud; J - CUOR 276, ventral internal mould, from locality PH1775 at Bou M'Haoud; K - CUOR 283, dorsal internal mould, from locality PH1859 at Bou M'Haoud. • C, F - ?Hirnantia sp. 1, locality PH1796, CUOR 299, Bou M'Haoud Formation, Lower Member (upper Sandbian-lower Katian) at Daïet en Noguir; C - CUOR 296, dorsal internal mould; F - CUOR 297, exfoliated dorsal valve exterior. • L - Hirnantia sagittifera (M'Coy, 1851), locality PH1812, Djebel Serraf Formation (Hirnantian) at Foum El Kseib, CUOR 291, enlarged latex cast of dorsal interior showing cardinalia. All scale bars are $2 \mathrm{~mm}$. 
locality PH467. One ventral internal mould, CUOR 260, and one dorsal internal mould, CUOR 261, from locality SY636 at Bou M'Haoud Village. One ventral internal mould, CUOR $355(\mathrm{Lv}=17.5, \mathrm{Ml}=6.5, \mathrm{Mw}=5.9$; Fig. 10D), and nine dorsal internal moulds, including CUOR 264, CUOR $265(\mathrm{Ld}=12.4, \mathrm{~W}=15.8, \mathrm{Iw}=11.4, \mathrm{Sl}=$ 4.1; Fig. 10E), CUOR 267 (Fig. 10F), CUOR 266, CUOR 354 (Fig. 10G), CUOR268 ( $\mathrm{Ld}=22.5, \mathrm{~W}=27.3, \mathrm{Iw}=$ 16.5, $\mathrm{Sl}=10.0$; Fig. 10H), CUOR269, CUOR $270(\mathrm{Ld}=$ $26.1, \mathrm{~W}=29.8, \mathrm{Iw}=22.2, \mathrm{Sl}=12.5$ ), CUOR 271, from locality SY640. Two dorsal internal moulds, including: CUOR 258 and CUOR 259, from locality PH1841 at Bou M'Haoud Village. Total eight ventral and 15 dorsal valves; all from Bou M'Haoud Formation, Upper Member (middle Katian) at the area of Bou M'Haoud Village.

Remarks. - This species, first described, illustrated and discussed in detail by Mergl (1983), is distinct for its exceptionally large size of a strongly dorsibiconvex shell, an elongate, suboval ventral muscle field (Fig. 10A), and subparallel brachiophore plates significantly shorter than the median ridge (Fig. 10D, F, H). In the studied shells a gently impressed, strongly elongate, subtriangular ventral adductor scar is about equal in length with narrow diductor scars, which was not originally reported from the types.

\section{Drabovinella regia Havlíček, 1971}

Figures 6B, C; 9A, B, D, E, J-L

1971 Drabovinella regia; Havlíček, p. 57, pl. 17, figs 1-5.

Holotype. - Dorsal internal mould illustrated by Havlíček (1970, pl. 17, figs 3, 4), Lower Ktaoua Formation (?upper Sandbian-lower Katian), Jebel Ahchach, Morocco.

Material. - Five ventral internal moulds, including: CUOR274 (Fig. 9H), CUOR 276 ( $\mathrm{Lv}=13.7, \mathrm{~W}=16.5$; Ml $=4.5, \mathrm{Mw}=4.5$; Fig. 9J), CUOR 277 (Fig. 9D), CUOR $278(\mathrm{Lv}=16.4, \mathrm{~W}=22.4 ; \mathrm{Ml}=6.6, \mathrm{Mw}=5.9$; Fig. 9I $)$, CUOR 279, and four dorsal internal moulds, including CUOR $272(\mathrm{Ld}=14.8, \mathrm{~W}=15.0, \mathrm{Iw}=9.5, \mathrm{BBl}=5.5$, $\mathrm{BBw}=3.9, \mathrm{Sl}=6.5$; Fig. 6B, C), CUOR $273(\mathrm{Lv}=10.7, \mathrm{~W}$ $=11.8 ; \mathrm{BBl}=3.7, \mathrm{BBw}=2.2, \mathrm{Sl}=4.2 ;$ Fig. $9 \mathrm{G}), \mathrm{CUOR}$ 275 (Fig. 9E), from locality PH1775, isolated outcrop at northern limb of Erg Chebbi. One ventral internal mould, CUOR 280, and one dorsal internal mould, CUOR 281, from locality PH1832 at Kheneg et Tlaïa. CUOR 282, Dorsal external mould (Fig. 9B), from locality PH1801 at Height $472 \mathrm{~m}$. Dorsal internal mould, from locality PH1855 at Kheneg et Tlaïa. Dorsal internal mould, CUOR 283 (Fig. 9K), from locality PH1859 NW of Bou M'Haoud Village. Dorsal internal mould, CUOR 284 $(\mathrm{Ld}=12.3, \mathrm{~W}=16.9, \mathrm{Iw}=13.9, \mathrm{Sl}=4.5, \mathrm{BBw}=2.4 ;$ Fig.
9A), from locality SY644 at Foum Tinneslem. Ventral internal mould, CUOR $285(\mathrm{Lv}=16.4, \mathrm{~W}=17.9, \mathrm{Ml}=$ $6.5, \mathrm{Mw}=3.8$ ), from Locality SY645 at Foum Tinneslem. Total seven ventral and nine dorsal valves from Bou M'Haoud Formation, Lower Member (?upper Sandbianlower Katian).

Description. - Shell subequally biconvex, slightly transverse, suboval in outline. Hinge line considerably shorter than maximum shell width at mid-length; cardinal extremities rounded. Anterior commissure rectimarginate. Ventral valve sagittal profile moderately convex with maximum height about one-third valve length from the umbo. Ventral interarea gently curved in a cross section, low, apsacline with an open, narrow, triangular delthyrium. Dorsal valve moderately and evenly convex. Dorsal interarea low, planar anacline to almost orthocline. Radial ornament multicostellate with 5 ribs per $2 \mathrm{~mm}$ at the anterior margin. Ribs rounded separated by narrow interspaces (Fig. 9B).

Ventral valve with teeth supported by thin, long, slightly divergent dental plates extending anteriorly into strong muscle-bounding ridges gradually fading anteromedially. Ventral muscle field cordate, about $100-138 \%$ as long as wide and $33-35 \%$, as long as the valve. Ventral adductor scars narrow, subtrangular, slightly raised anteriorly, and completely dividing longer, gently impressed diductor scars (Fig. 9D, H-J). Pedicle callist small, subtriangular, undercut anteriorly (Fig. 9I). Ventral mantle canals lemniscate with straight, divergent vascula media (Fig. 9I, J). Dorsal interior with a simple, blade-like cardinal process thickened posteriorly and occluding a narrow notothyrial cavity with a long shaft merged anteriorly with the median septum. Brachiophores supported thin, long, blade-like with almost straight, subparallel bases curved inward near anterior termination, but not merged with the median septum. Median septum thin, terminated at about $40 \%$ of valve length from the umbo at a level or slightly anterior in relation to the anterior terminations of brachiophore plates (Figs 6B, C; 9A, G). Fulcral plates well developed (Fig. 6B) Adductor scars and mantle canals not impressed.

Remarks. - Original description of the species was based on a limited number of specimens including a single dorsal internal mould. While some dorsal valves (e.g. Figs 6, B, C; 9A) in characters of cardinalia are almost indistinguishable from the holotype illustrated by Havlíček (1971, pl. 17, figs 3, 4), there are also specimens with a dorsal median septum extending beyond the anterior terminations of the brachiophore bases (Fig. 9E). Also the ventral muscle scars in the Algerian shells are more strongly impressed, than in the ventral valves illustrated by Havlíček (1971). 

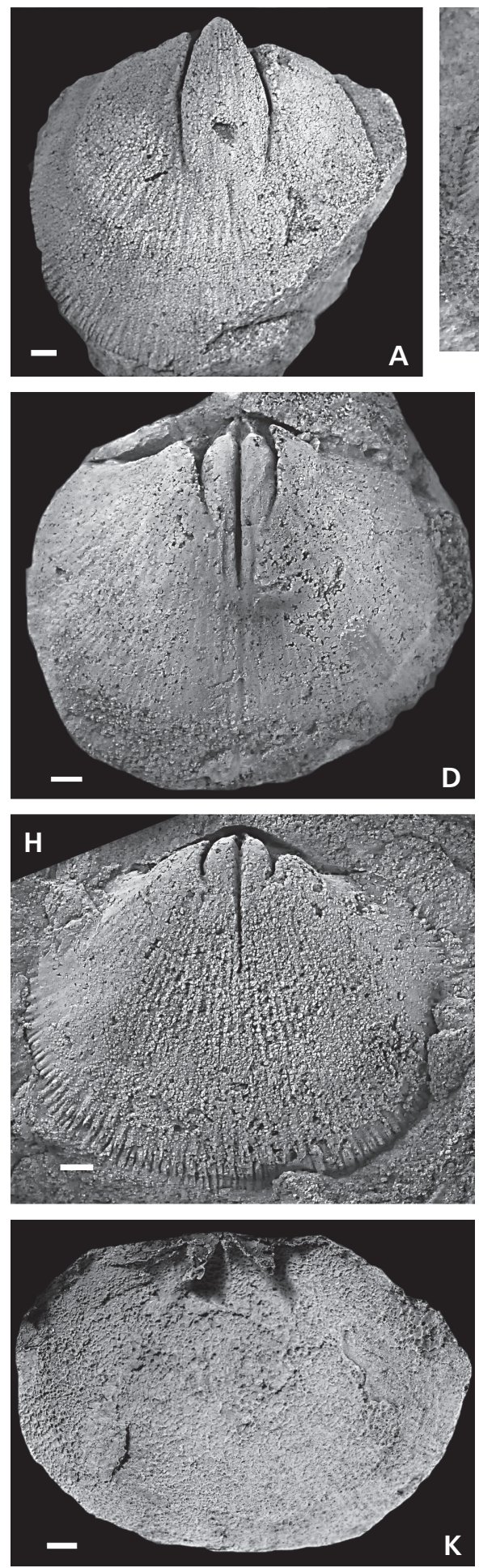
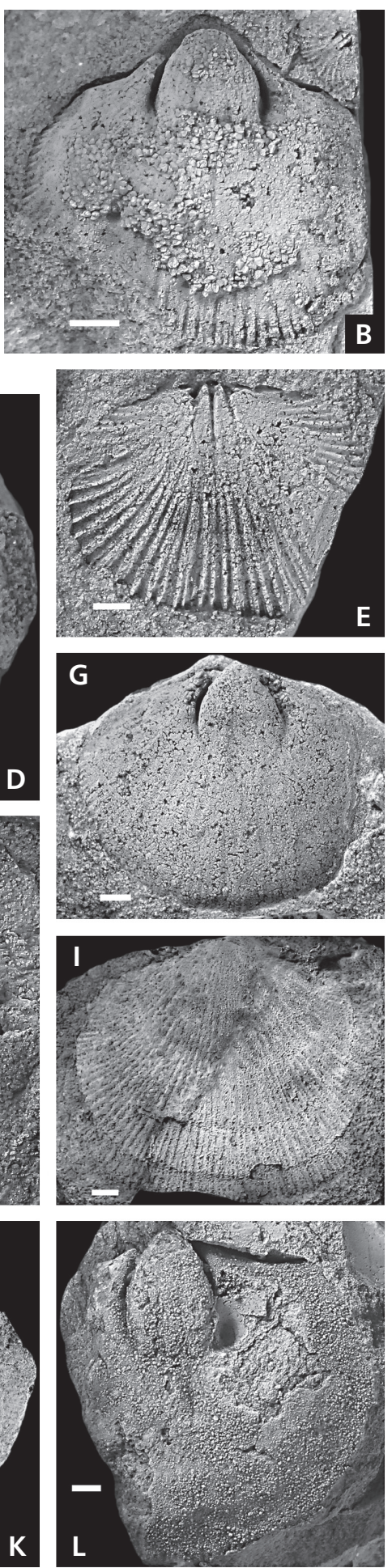
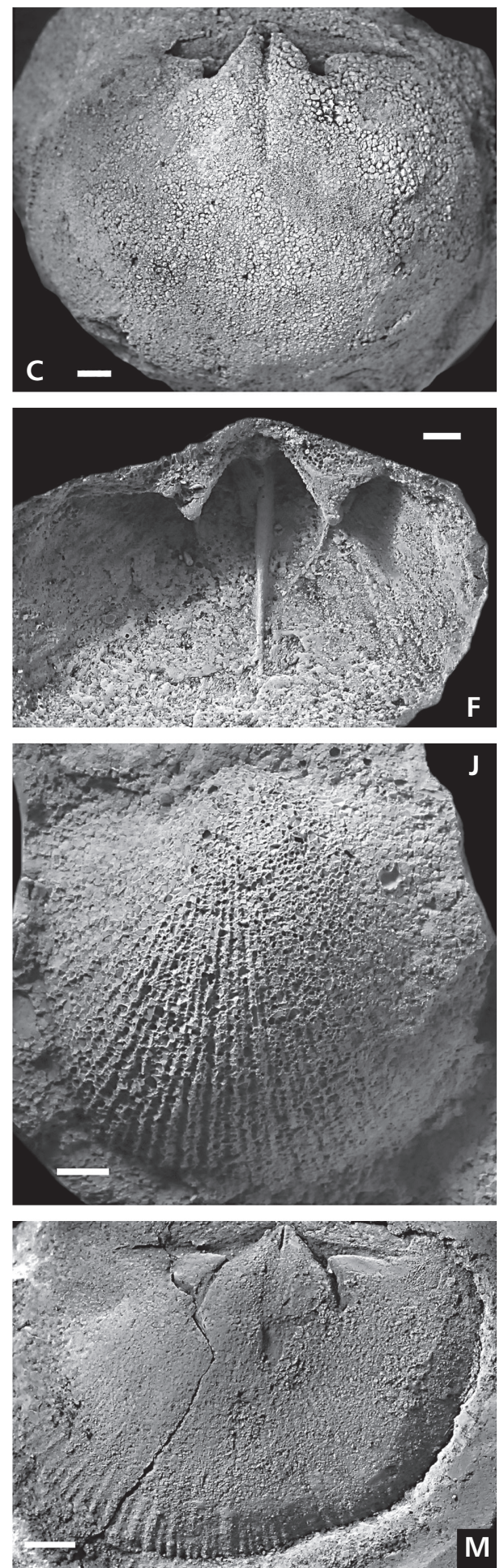

Figure 10. A, B, D-H - Drabovinella maxima Mergl, 1983, Bou M’Haoud Formation, Upper Member (middle Katian), Bou M'Haoud; A - CUOR 250, ventral internal mould, from locality PH466; B - CUOR 251, ventral internal mould, from locality PH466; D - CUOR 355, dorsal internal mould, from locality SY640 at Bou M'Haoud; E - CUOR 265, dorsal internal mould of juvenile individual, from locality SY640 at Bou M'Haoud; F - CUOR 267, latex cast of dorsal valve interior, from locality SY640 at Bou M'Haoud; G - CUOR 354, ventral internal mould, from locality SY640 at Bou M'Haoud; H - CUOR268, dorsal internal mould, from locality SY640 at Bou M'Haoud. • C - ?Hirnantia sp. 2, locality PH466, Bou M'Haoud Formation, Upper Member (middle Katian), Bou M'Haoud, CUOR 299, dorsal internal mould. • I-M - Hirnantia sagittifera (M'Coy, 1851), Djebel Serraf Formation (Hirnantian); I - CUOR 289, latex cast of ventral valve exterior, from locality PH450, Ougarta Village; J - CUOR 292, latex cast of dorsal valve exterior, from locality at Foum El Kseib; K - CUOR 291, latex cast of dorsal interior, from locality PH1812 at Foum El Kseib; L - CUOR 356, ventral internal mould from locality PH237 at Ougarta Village; M - CUOR 288, dorsal internal mould from locality PH237 at Ougarta Village. All scale bars are $2 \mathrm{~mm}$. 
Affinities of Drabovinella regia to the Bohemian species of Drabovinella were discussed in detail by Havlíček (1971). It differs from another Algerian species Drabovinella maxima in smaller sizes, shorter, distinctly cordate ventral muscle field and characters of the cardinalia with long subparalel brachiophore plates and a significantly shorter dorsal median ridge.

\section{Genus Hirnantia Lamont, 1935}

Type species. - By original designation Orthis sagittifera M'Coy, 1851.

\section{Hirnantia sagittifera (M'Coy, 1851)}

Figures 9L, 10I-M

1851 Orthis sagittifera; M'Coy, p. 398.

1977 Hirnantia sagittifera (M'Coy, 1851). - Havlíček, p. 266, pl. 29, figs 15-23 (full synonymy).

1983 Hirnantia sagittifera (M'Coy, 1851). - Mergl, p. 343, pl. 4, figs 14-16.

2008 Hirnantia sagittifera (M'Coy, 1851). - Cocks, p. 167 (full synonymy).

Lectotype. - Selected by Temple (1965), SM A41217, Hirnant Formation (Hirnantian) of Aber Hirnant, Bala, Gwynnedd, Wales.

Material. - One ventral internal mould, including CUOR 286, from locality PH137 at Ougarta Village. Four ventral internal and external moulds, including CUOR 356 (Fig. 10L), and one dorsal internal mould CUOR 288, from locality PH237 at Ougarta Village. Two dorsal external moulds, including CUOR $289(\mathrm{Ld}=22.4, \mathrm{~W}=26.0, \mathrm{~T}=$ 4.7; Fig. 10I) and CUOR 290, from locality PH450 at Foum El Kseib. One ventral internal mould, CUOR 291 (Fig. 9L), one dorsal external mould, CUOR 292 (Fig. 10J), and one dorsal internal mould CUOR 293, from locality SY609 at Foum El Kseib. Two dorsal internal moulds, including: CUOR 294 and CUOR 295, from locality SY609 at Foum El Kseib. Total six ventral and seven dorsal valves, all specimens are from Djebel Serraf Formation, Ougarta Ksar Member sandstones (upper Hirnantian).

Remarks. - Occurrence of Hirnantia sagittifera in the Djebel Serraf Formation of southern Ougarta Range was first reported by Havlíček (1971) who noted the occurrence of the species in locality 2012 at Jebel Heche, south-eastern Ougarta Range. These shells were probably derived from the Djebel Serraf Formation. Subsequently Algerian specimens of Hirnantia sagittifera from the same locality were illustrated by Mergl (1983). The newly available specimens are strongly similar with those illustrated in the cited publication and considered here as conspecific. Shells of Hirnantia aff. sagittifera briefly described by Havlíček \& Massa (1973) from the Memouniat Formation of Oued Kedawal in Libya are not included into the synonymy because of morphological differences from typical representatives of the species reported in the cited publication and also due to insufficient illustration.

\section{?Hirnantia sp. 1}

Figures 7U; 9C, F

Material. - Ventral internal mould, CUOR $298(\mathrm{Lv}=18.5$, $\mathrm{W}=27.2, \mathrm{Iw}=21.0, \mathrm{Ml}=6.9, \mathrm{Mw}=5.0 ;$ Fig. $7 \mathrm{U})$, from locality PH1797; dorsal internal mould, CUOR 296 (Fig. 9C), and dorsal external mould, CUOR 297 (Fig. 9F), from locality 1796; all specimens from Bou M'Haoud Formation, Lower Member (?upper Sandbian-lower Katian) of Foum opposite of Daïet en Nouguir.

Remarks. - A single dorsal internal mould shows a simple cardinal process on a thin ridge-like shaft projecting anteriorly as a faint median ridge bisecting weakly impressed adductor muscle scars and delicate brachiophores supported by thin, divergent brachiophores supports. Anterior terminations of brachiophores supports extend as short convergent ridges bounding inner posterior margins of the dorsal adductor muscle scars (Fig. 9C), recalling Hirnantia ulrichi (Havlíček, 1951) from the Letná Formation (upper Sandbian) of Bohemia. The ventral internal mould questionably associated with the same taxon is characterised by a slightly elongate, suboval, open anteriorly muscle field occupying about onethird sagittal valve length, long, divergent dental plates extended anteriorly as gently curved muscle bounding ridges, delineating weakly impressed ventral diductor muscle scars laterally. The shells may represent an unnamed early species of Hirnantia; however, available material is not enough for precise generic discrimination.

\section{?Hirnantia sp. 2}

Figure 10C

Material. - One dorsal internal mould, CUOR 299, from locality PH466 at vicinity of Bou M'Haoud Village, Bou M'Haoud Formation, upper member (middle Katian).

Remarks. - A single specimen represented by dorsal internal mould is characterised by a strongly convex dorsal valve with a rectimarginate anterior commissure. A simple cardinal process on a long shaft extends anteriorly as a low median ridge bisecting the weakly impressed adductor muscle field. Brachiophore plates are strong, widely divergent with anterior terminations touching 
posterolateral margins of the dorsal adductor muscle field. It recalls the specimen of Hirnantia sp. A, from the upper Ktaoua Formation of Anti-Atlas, Morocco, but differs in having shorter and strongly thickened brachiophores supports and in the absence of distinct traces of dorsal umbonal sulcus. Generic affiliation of the specimen is provisional due to insufficient material.

Order Pentamerida Schuchert \& Cooper, 1931

Suborder Syntrophiidina Ulrich \& Cooper, 1936

Superfamily Camerelloidea Hall \& Clarke, 1895

Family Camerellidae Hall \& Clarke, 1895

Subfamily Camerellinae Hall \& Clarke, 1895

\section{Camerellinae gen. et sp. indet.}

Figure 11A

Material. - Dorsal external mould, CUOR 300, from locality PH1837, at Bou M'Haoud Ravine, Bou M'Haoud Formation, top of Lower Member (?upper Sandbian).

Remarks. - A single small dorsal valve with paucicostate radial ornament of strong rounded ribs with a pair of strong medial ribs originating in front of the beak definitely represents a pentameride. Distribution of side ribs is highly asymmetrical. While attribution of the shell to Camerellainae looks possible, generic assignation cannot be made without data on the interiors of both valves.

Order Rhynchonellida Kuhn, 1949

Superfamily Rhynchotrematoidea Schuchert, 1913

Family Trigonirhynchiidae McLaren, 1965 in Moore (1965)

Remarks. - There is a clear statement in Moore (1965, p. H559) that McLaren is responsible for designation of the family Trigonirhynchiidae. However, the taxon was also introduced by Schmidt (1965) in the paper published earlier the same year and it has a priority (see Savage et al. 2002).

Subfamily Rostricellulinae Rozman, 1969

\section{Genus Rostricellula Ulrich \& Cooper, 1942}

Type species. - By original designation Rostricellula rostrata Ulrich \& Cooper, 1942.

\section{Rostricellula ambigena (Barrande, 1847)}

\section{Figure 11B-E}

1847 Terebratula ambigena; Barrande, p. 88, pl. 20, fig. 11. 1961 Rostricellula ambigena (Barrande, 1847). - Havlíček, p. 50; pl. 3, figs 4-6, 8, 19; text-fig. 9 (full synonymy).
1985 Rostricellula ambigena (Barrande, 1847). - Villas, p. 120, pl. 34, figs 9-14 (full synonymy).

2015 Rostricellula cf. ambigena (Barrande, 1847). - Popov et al., p. 416, figs 9d, e, 15d.

2015 Rostricellula ambigena (Barrande, 1847). - Colmenar \& Álvaro, figs 8f, 9e, f.

Neotype. - Selected by Havlíček (1961), CBNM-ČE 1531, articulated shell from Králův Dvůr Formation (upper Katian), Prague Basin, Czech Republic.

Material. - Three ventral valves, including CUOR 301, CUOR 303 and CUOR 305, and two dorsal valves, CUOR 304 and CUOR $302(\mathrm{Ld}=6.5, \mathrm{~W}=7.4$; Fig. 11D, E), from locality PH1836. One ventral external mould CUOR 306, and one ventral internal mould CUOR 307, from locality PH1856. One ventral valve, CUOR $357(\mathrm{Lv}=8.4$, $\mathrm{W}=8.2, \mathrm{Sw}=4.3$; Fig. $11 \mathrm{C}$ ), and five variably exfoliated dorsal valves, including: CUOR 308 (Fig. 11B), CUOR 309, CUOR 310, CUOR $311(\mathrm{Ld}=7.5, \mathrm{~W}=8.9, \mathrm{Sw}=$ 4.2), CUOR 312, from locality PH1860. One dorsal valve, CUOR $313(\mathrm{Ld}=6.0, \mathrm{~W}=6.5, \mathrm{Sw}=3.2)$, from locality PH1861. Total six ventral and eight dorsal valves; all from Bou M'Haoud Formation, Middle Member at Kheneg et Tlaïa.

Remarks. - Rostricellula ambigena was revised by Havlíček (1961) who presented detailed description and illustrations of the taxon, while interiors of both valves shown in transverse serial sections. The Algerian shells are characterised by slightly dorsibiconvex shell with one rib on the ventral sulcus, two ribs on the dorsal fold and 4-6 ribs on the lateral sides of both valves. A dorsal interior exhibits a disjunct hinge plate, and a narrow septalium lacking cardinal process and supported by a thin median septum. Observed features leave no doubts about the species affiliation of the Algerian shells. Havlíček (1961) reported occasional bifurcation of ribs on the full grown shells of Rostricellula ambigena from Bohemia; however, this feature is not characteristic of the Algerian representatives of the species and observed on a single specimen.

Occurrence of Rostricellula ambigena in the uppermost Lower Ktaoua and Upper Tiouririne formations of Anti-Atlas, Morocco is recently documented by Colmenar \& Álvaro (2015). The specimens illustrated in the cited publication, including ventral and dorsal internal moulds, are closely similar and certainly conspecific with the Algerian shells.

Rostricellula cf. ambigena briefly described and illustrated by Popov et al. (2015) from south-west of Anarak in Central Iran is known only from exteriors of both valves. As well as without data on the dorsal valve morphology species affiliation of these shells cannot be 
confirmed with confidence they are not included into the synonymy.

Rhynchonellides are relatively uncommon in the Sandbian-Katian of the Mediterranean sector of Gondwana. Among them Rostricellula arabica Wolfart, 1968 in Wolfart et al. (1968), from the Upper Ordovician of Jordan differs from Rostricellula ambigena mainly in having three simple ribs in the ventral sulcus and four ribs on the dorsal median fold. Another taxon is "Rhynchotrema" cf. clariondi Termier \& Termier, 1950 from the Melez Chograne Formation (Sandbian) of Fezzan, Libya. Possible synonymy of these shells with Rostricellula arabica cannot be excluded, but without data on the interiors of both valves their generic affiliation in present cannot be resolved.

\section{Genus Plectothyrella Temple, 1965}

Type species. - By original designation Plectothyrella platystrophoides Temple, 1965.

[= ?Atrypa crassicostis Dalman, 1828]

\section{Plectothyrella crassicostis chauveli Havlíček, 1971 Figure $11 \mathrm{~F}-\mathrm{R}$}

1971 Plectothyrella chauveli Havlíček; 25, figs 4-12.

1998 Plectothyrella crassicosta chauveli Havlíček. - Villas et al., p. 193, fig. 4j-o.

Holotype. - Incomplete shell external mould illustrated by Havlíček (1971, pl. 25, fig. 12); locality 1551, Djebel Serraf Formation (Hirnantian), Ougarta Village, Algeria.

Material. - Two articulated shells preserved as internal and external moulds, including: CUOR 319 and CUOR 320 (Fig. 11K); eight ventral internal moulds, including: CUOR 315 (Fig. 11Q), CUOR 317 (Fig. 11P), CUOR 318, CUOR 322, CUOR 323, CUOR 324 (Fig. 11H); CUOR 324, CUOR 361 (Fig. 11M), and five dorsal internal moulds, including CUOR 314, CUOR 316, CUOR 321 $(\mathrm{Ld}=14.7, \mathrm{~T}=5.0, \mathrm{Sw}=8.0$; Fig. $11 \mathrm{~S})$, CUOR 362 , CUOR 363 (Fig. 11F), from localities PH237 and PH237bis; dorsal internal mould, PH1842/a1, from locality PH1842; eight ventral internal and external moulds, including: CUOR 325, CUOR 326, CUOR 334, CUOR 335, CUOR 337, CUOR 330 (Fig. 11N, O), CUOR 357 (Fig. 11I), CUOR 331 (Fig. 11N, O), CUOR 340, and six dorsal external and internal moulds, including CUOR 327, CUOR328, CUOR329, CUOR 332, CUOR 336, CUOR 333, from locality SQ449. One ventral internal mould, from locality SQ450. Total two articulated shells, 17 ventral and 15 dorsal valves from Djebel Serraf Formation (Hirnantian) at Ougarta Village. One ventral valve, CUOR 341 (Fig. 11J); and five dorsal internal and external moulds, including CUOR 342, CUOR $343(\mathrm{Ld}=5.2, \mathrm{~W}=6.4)$, CUOR $344(\mathrm{Ld}=4.3, \mathrm{~W}=4.5)$, CUOR 345, CUOR 346 $(\mathrm{Ld}=7.3, \mathrm{~W}=8.8$; Fig. 10L $)$, from locality SY606 from Djebel Serraf Formation (Hirnantian) at Foum El Kseib.

Description. - Shell strongly and subequally biconvex, varying from slightly transverse to slightly elongate suboval in outline, with a short hinge line and maximum width at mid-length, Anterior commissure strongly uniplicate. Ventral valve strongly and evenly convex with a swollen, strongly incurved and beak and a broad, open, triangular delthyrium with vestigial delthyrial plates (Fig. 11M, N). Ventral sulcus originating slightly anterior to the umbo, gradually deepening and widening posteriorly, terminated with a moderately high subtrapezoidal tongue. Dorsal valve sagittal profile strongly and evenly convex with maximum height at mid-length. Dorsal umbo strongly swollen, curved, almost completely blocking the delthyrial opening on the opposite valve. Umbonal area with a very shallow sulcus replaced at $2-3 \mathrm{~mm}$ from the umbo by a median fold (Fig. 11L). Radial ornament of strong, subangular ribs, separated by interspaces of about equal width, with three-five ribs on the sulcus and four six ribs on the median fold of the adult shells. The umbonal area with one rib on the sulcus and two ribs on the median fold bifurcating internally at $3-4 \mathrm{~mm}$ from the umbo (Fig. 11L). Additional pair of ribs originated occasionally in the anterior part of the shell in larger individuals, while the third pair of secondary ribs observed in the ventral valve of the single individual. The median rib in the ventral sulcus often accentuated. Flanks of both valves with 8-11 simple ribs. Concentric ornament with fine regularly spaced fila, usually poorly preserved, and a few thin growth lamellae near the margins of the mature individuals.

Figure 11. A - Camerellainae gen. et sp. indet., locality PH1837, Bou M'Haoud Formation, lower Member (lower Katian) at Bou M'Haoud Ravine, CUOR 300, latex cast of dorsal valve exterior. - B-E - Rostricellula ambigena (Barrande, 1847), Bou M'Haoud Formation, Middle Member (lower Katian) at Kheneg et Tlaïa; B - CUOR 308, dorsal valve exterior, from locality PH1860; C - CUOR 357, ventral valve exterior, from locality PH1860; D, E - CUOR 302, latex cast of dorsal valve interior and dorsal internal mould, from locality PH1836. $\bullet$ F-S - Plectothyrella crassicostis chauveli Havlíček, 1971, Djebel Serraf Formation (Hirnantian); F - CUOR 363, dorsal internal mould, from locality PH237 at Ougarta Village; G-CUOR 340, ventral internal mould, from locality SQ449 at Ougarta Village; H - CUOR 324, ventral internal mould, from locality PH237 at Ougarta Village; I - CUOR 357, ventral internal mould, from locality SQ449 at Ougarta Village; J - CUOR 341, dorsal internal mould, from locality SY606; K - CUOR 320, dorsal internal mould, from locality PH237 at Ougarta Village; L - CUOR 346, latex cast of dorsal valve exterior, from locality SY606; M - CUOR 361, latex cast of ventral valve exterior, from locality SQ449 at Ougarta Village; N, O - CUOR 330 and CUOR 331, latex casts of ventral 

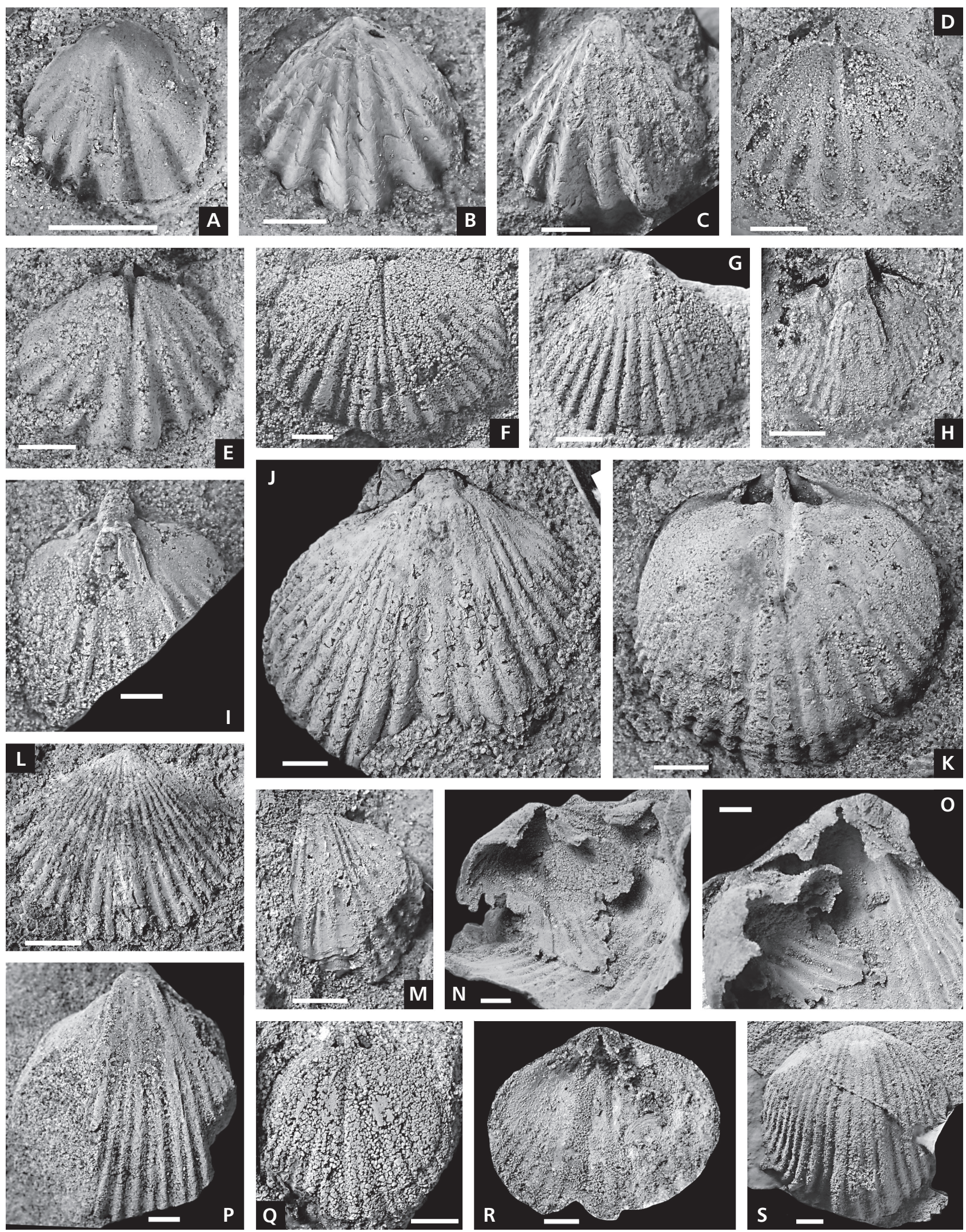

valve exteriors from locality SQ449 at Ougarta Village; P - CUOR 317, ventral internal mould, from locality PH237bis at Ougarta Village; Q - CUOR 315 , dorsal internal mould, from locality PH237bis at Ougarta Village; R - CUOR 316, latex cast of dorsal valve interior, from locality PH237 at Ougarta Village; S - CUOR 321, latex cast of dorsal valve exterior from locality PH237bis. All scale bars are $2 \mathrm{~mm}$. 
Ventral interior with strong, hook-like cyrtomatodont teeth supported by the short, rudimentary dental plates. Floor of the deep delthyrial cavity occupied mainly by the pedicle collar. Ventral muscle field gently impressed, large, elongate subtriangular, confined laterally by thin, straight, divergent muscle bounding ridges (Fig. 11H, I). The boundaries between individual muscle scars not recognisable. Dorsal interior with a disjunct hinge plate, small narrow septalium supported by the low, thick median septum terminated at about mid-length (Fig. 11F, $\mathrm{K}, \mathrm{R})$. Crura thin, radulifer curved ventrolaterally. Dorsal adductor muscle field not impressed.

Remarks. - The species was originally described by Havlíček (1971) based on limited material, in particular, only a single ventral valve interior was available for study, while character of rib bifurcation in the ventral sulcus and dorsal median fold was not observed. It is important to note that most of the specimens illustrated by Havlíček (1971), including holotype, originated from the Djebel Serraf Formation exposed in the area of Ougarta Village, Algeria, which is commonly overlooked. Therefore, a significant number of specimens in our collection represent topotypes. In these specimens rib bifurcations occur only in the ventral sulcus and dorsal median fold, while flanks are ornamented by simple ribs. While the patterns of radial ornament in Plectothyrella crassicostis chauveli show significant range of variation, there is a large proportion of specimens with three ribs in the ventral sulcus and four ribs on the flanks of the ventral valve (Fig. 11C, J-L, S), which are almost indistinguishable from Plectothyrella crassicostata (Temple, 1965; Bergström 1968). Yet rib bifurcations in the Algerian shells occur closer to the umbo, while larger number of ribs (5 against $3-4)$ per $5 \mathrm{~mm}$ at $10 \mathrm{~mm}$ from the umbo is probably due to the narrower ventral sulcus and dorsal median fold. These data confirm earlier observations made by Villas et al. (1998) and following the cited publication Plectothyrella crassicostis chauveli is considered here as a geographical variation of a widespread and morphologically variable species. Restudy of topotypes of Plectothyrella crassicostis chauveli suggest also that variations in characters of radial ornamentation in the shells, assigned by Marek \& Havlíček (1967) and Havlíček (1990) to Plectothyrella crassicostata, are within the range of the Algerian population, and both should be assigned to the same taxon.

Shells from Criadero Quartzite of Almadén in Central Spain (Villas et al. 1998) assigned to Plectothyrella crassicostis chauveli are closely similar to the topotypes in characters of radial ornamentation, while the shells from the Don Braulio Formation of Argentinian Precordillera (Astini \& Benedetto 1992) show numerous rib bifurcations on the flanks of both valves and should be considered as a different taxon.

\section{Acknowledgements}

Leonid Popov and Mansoureh Ghobadi Pour acknowledge the logistical support provided by the National Museum of Wales. The research carried out in Iran by Mansoureh Ghobadi Pour was supported by the Golestan University. We are grateful to John Cope, National Museum of Wales, Cardiff for helpful comments on the earlier version of the manuscript. The paper is greatly benefited from constructive reviews of Michal Mergl, University of West Bohemia, Pilsen and Juan L. Benedetto, Universidad Nacional de Córdoba.

\section{References}

Arbey, F. 1962. Données nouvelles sur la sédimentation au Cambro-Ordovicien dans les Monts d'Ougarta (Saoura). Comptes rendus de l'Académie des Sciences, Paris 254, 3726-3728.

Arbey F. 1968. Structures et dépôts glaciaires dans l'ordovicien terminal des chaînes d'Ougarta (Sahara Algérien). Comptes rendus de l'Académie des Sciences, Paris 266, 76-78.

Astini, R.A. \& Benedetto, J.L. 1992. El Ashgilliano tardío (Hirnantiano) del cerro La Chilca, Precordillera de San Juan, Argentina. Ameghiniana 29, 249-264.

Barrande, J. 1847, 1848. Über die Brachiopoden der silurischen Schichten von Böhmen. Naturwissenschaftliche Abhandlungen 1 (1847), 357-475; 2 (1848), 155-256.

Barrande, J. 1879. Système Silurien du Centre de la Bohème, lère Partie, Recherches Paléontologiques, vol. 5. Classe des Mollusques: Ordre des Brachiopodes. 226 pp. Privately published, Paris.

Bassett, M.G., Popov, L.E., Aldridge, R.J., Gabbott, S.E. \& Theron, J.N. 2009. Brachiopoda from the Soom Shale Lagerstätte (upper Ordovician, South Africa). Journal of Paleontology 83, 614-623. DOI 10.1666/08-136.1

Bergström J. 1968. Upper Ordovician brachiopods from Västergötland, Sweden. Geologica et Paleontologica 2, 1-35.

Billings, E. 1872. On some fossils from the primordial rocks of Newfoundland. Canadian Naturalist and Geologist (new series) 6, 465-479.

Cocks, L.R.M. 2008. A revised review of British Lower Palaeozoic brachiopods. Monograph of the Palaeontographical Society, London 629, 1-276. 1-10.

Cocks, L.R.M. \& Lockley, M.G. 1981. Reassessment of the Ordovician brachiopods from the Budleigh Salterton Pebble Bed, Devon. Bulletin of the British Museum (Natural History), London, Geology 35, 111-124.

Colmenar, J. \& Álvaro, J.J. 2015. Integrated brachiopodbased bioevents and sequence-stratigraphic framework for a Late Ordovician subpolar platform, eastern Anti-Atlas, Morocco. Geological Magazine 152, 603-620. DOI 10.1017/S0016756814000533

Colmenar, J., Harper, D.A.T. \& Villas, E. 2014. Morphofunctional analysis of Svobodaina species (Brachiopoda, Heterorthidae) from southwestern Europe. Palaeontology 57, 193-214. DOI 10.1111/pala.12061 
Colmenar, J., Villas, E. \& Vizcaino, D. 2013. Upper Ordovician brachiopods from the Montagne Noire (France): endemic Gondwanan predecessors of Prehirnantian lowlatitude immigrants. Bulletin of Geosciences 88, 153-74. DOI 10.3140/bull.geosci.1352

Cooper, G.A. 1956. Chazyan and related brachiopods. Smithsonian Miscellaneous Collections 127, 1-1245.

Dalman, J.W. 1828. Upställning och Beskrivning af de i sverige funne Terebratuliter. Kunglinga Vetenskapsakademien Handlingar for Ar 1827, 85-155.

DAVIDSON, T. 1880. On the Species of Brachiopoda that characterize the "Grès Armoricain" of Brittany, together with a few observations on the budleigh salterton pebbles. Geological Magazine 7, 337-343. DOI 10.1017/S0016756800148058

DAVIDSON, T. 1881. Monograph of the British Fossil Brachiopoda, Vol. 4, Part 4: Devonian and Silurian Brachiopoda that occur in the Triassic pebble bed of Budleigh Salterton, in Devonshire). Monograph of the Palaeontographical Society, London 35, 317-368. DOI 10.1080/02693445.1881.12027966

Destombes, J. 1968. Sur la présence d'une discordeance générale de ravinement d'âge Ashgill supérieur dans 1'Ordovicien terminal de 1'Anti-Atlas (Maroco). Comptes rendus de l'Académie des Sciences, Paris 267, 565-567.

Destombes, J. 2004. Mémoire explicatif des cartes géologiques au 200000 de l'Anti-Atlas marocain - Cambrien moyen et supérieur, Ordovicien, base du Silurien. (unpublished report).

Elaouad-Debbaj, Z. 1984. Acritarches et chitinozoaires de 1'Arenig-Llanvirn de 1'Anti-Atlas (Maroc). Review of Paleobotany and Palynology 43, 67-88. DOI 10.1016/0034-6667(84)90027-7

Ghavidel-Syooki, M., Popov, L.E., Alvaro, J.J., Ghobadi Pour, M., Tolmacheva, T.Y. \& Ehsani, M.H. 2014 a. Dapingian-lower Darriwilian (Ordovician) stratigraphic gap in the Faraghan Mountains, Zagros Ranges, south-eastern Iran. Bulletin of Geosciences 89, 679-706. DOI 10.3140/bull.geosci.1453

Ghavidel-Syooki, M., Popov, L.E., Ghobadi Pour, M., Alvaro, J.J. \& Ehsani, M.H. 2014b. Late Ordovician and early Silurian brachiopods from the Zagros Ranges, Iran. Earth and Environmental Science Transactions of the Royal Society of Edinburgh 105, 159-187. DOI 10.1017/S1755691015000079

Ghienne, J.F., Boumendjel, K., Paris, F., Videt, B., Racheboeuf, P. \& Salem, H.A. 2007. The Cambrian-Ordovician succession in the Ougarta Range (western Algeria, North Africa) and interference of the Late Ordovician glaciation on the development of the Lower Palaeozoic transgression on northern Gondwana. Bulletin of Geosciences 82, 183-214. DOI 10.3140/bull.geosci.2007.03.183

Gómes Silva, M., Pacaud, M. \& Wiel, F. 1963. Contribution à l'étude du Cambro-Ordovician des chaînes d'Ougarta (Sahara algérien). Bulletin de la Société géologique de France 7, 134-141.

Gorjansky, V.Yu. \& Popov L.E. 1985. Morphology, systematic position and origin of the inarticulated brachiopods with calcareous shells. Paleontologicheskii Zhurnal 1985(3), $3-14$.
GrAY, J.E. 1840. Synopsis of the contents of the British Museum, $42^{\text {nd }}$ edition. 370 pp. British Museum, London.

Gutiérrez-Marco, J.C., Destombes, J., Rabano, I., Acenolaza, G.F., SARmiento, G.N. \& SAN José, M.S. 2003. El Ordovicico Medio del AntiAtlas maroqui; paleodiversidad, actualizacion bioesstratigrafica y correlacion. Geobios 36, 151-177. DOI 10.1016/S0016-6995(03)00004-4

Gutiérrez-Marco, J.C., SÁ, A.A., García-Bellido, D.C. \& RÁbano, I. 2014. The extent of the Middle Ordovician Dapingian Stage in peri-Gondwanan Europe and north Africa: stratigraphic record, biostratigraphic tools and regional chronostratigraphy. GFF 136, 90-94. DOI 10.1080/11035897.2013.865667

Hall, J. \& Clarke, J.M. 1892-1895. An introduction to the study of the genera of Palaeozoic Brachiopoda. New York State Geological Survey, Palaeontology of New York 8(1), $1-367 ; 8(2), 1-394$.

Hall, J. \& Whitfield, R.P. 1875. Descriptions of invertebrate fossils mainly from the Silurian System. Fossils of the Hudson River Group. Geological Survey of Ohio, Report 2, part 2, 67-110.

Harper, D.A.T. 2007. Order Orthida, 2684-2697. In Selden, P.A. (ed.) Treatise on Invertebrate Paleontology, Part H, Brachiopoda (revised), Vol. 6: Supplement. Geological Society of America and University of Kansas Press, Boulder \& Lawrence.

HavlíčEK, V. 1951. The Ordovician Brachiopoda from Bohemia. Rozpravy Ústředního ústavu geologického 13 (1950), 1-135.

HAVLíČEK, V. 1961. Rhynchonelloidea des böhmischen älteren Paläozoikums (Brachiopoda). Rozpravy Ústředního ústavu geologického 27, 1-211.

HavlíčEK, V. 1970. Heterorthidae (Brachiopoda) in the Mediterranean Province. Sbornik Geologických věd, Paleontologie $12,7-40$.

HAVlíčEK, V. 1971. Brachiopodes de l'Ordovicien du Maroc. Notes et Mémoires du Service Géologique du Maroc 230, $1-135$.

HAvLíčEK, V. 1977. Brachiopods of the order Orthida in Czechoslovakia. Rozpravy Ústředního ústavu geologického $44,1-327$.

HAVLÍČEK, V. 1980. Inarticulate brachiopods in the Lower Ordovician of the Montagne Noire (South France). Mémoire de la Société d'Études Scientifiques de l'Aude 1980, 3-11.

HavlíčEK, V. 1990. Mediterranian and Malvinokaffric Province: new data on the Upper Ordovician and Lower Silurian brachiopods. Časopis pro mineralogii a geologii 35, 1-14.

HAVLíčEK, V. \& MASSA, D. 1973. Brachiopodes de l'Ordovicien supérieur de Libye occidentale: Implications stratigraphiques régionales. Géobios 6, 267-290. DOI 10.1016/S0016-6995(73)80020-8

Holmer, L.E. \& Popov, L.E. 2000. Subphylum Linguliformea, 30-146. In KAesler, R.G. (ed.) Treatise on Invertebrate Paleontology, part $H$ (revised), Brachiopoda, vol. 2. The Geological Society of America and the University of Kansas Press, Boulder \& Lawrence.

JaAnusson, V. \& Bassett, M.G. 1993. Orthambonites and related Ordovician brachiopod genera. Palaeontology 36, 21-63. 
KING, W. 1846. Remarks on certain genera belonging to the class Palliobranchiata. Annals and Magazine of Natural History (series 1) 18, 26-42, 83-94.

Kunn, O. 1949. Lehrbuch der Paläozoologie. v + 326 pp., 244 figs. E. Schweizerbart, Stuttgart.

Kutorga, S.S. 1848. Ueber die Brachiopoden-Familie der Siphonotretaceae. Russisch-Kaiserliche Mineralogische Gesellschaft zu St. Petersbourg, Verhandlungen 1847, 250-286.

Lamont, A. 1935. The Drummuck Group, Girvan; a stratigraphical revision, with descriptions of new fossils from the lower part of the group. Geological Society of Glasgow Transactions 19, 288-334. DOI 10.1144/transglas.19.2.288

LEgRAND, P. 1964. Un graptolite intéressant de l'Arénigien supérieur du Sahara algérien: Didymograptus v-fractus wieli nov subsp. Comptes rendus sommaires de la Société géologique de France 9, 360-363.

Legrand, P. 1971. A propos de la présence de Dinobolus (?) aff. brimonti (M. Rouault) au Sahara Algérien. Mémoires $d u$ Bureau des Recherches Géologiques et Minières 73, 79-87.

LEgrand, P. 1974. Essai sur la paléogéographie de l'Ordovicien au Sahara algérien. Compagnie Française des Pétroles, Notes et Mémoires 11, 121-138.

Legrand, P. 1985a. Lower Palaeozoic Rocks of Algeria, 5-89. In Holland, C.H. (ed.) Lower Palaeozoic of north-wetern and west central Africa, Lower Palaeozoic Rocks of the world 3.

Legrand, P. 1985b. Réflexions sur la transgression silurienne au Sahara algérien. Actes $110^{\text {èmes }}$ Congrès nat. Soc Savantes, Géologie Africaine, 233-244.

LEGRAND, P. 1986. Nouvelles observations sur la formation de Bou M'haoud (Ordovicien) dans les Monts d'Ougarta. 6éme séminaire national des sciences de la Terre, (Abstract), (Supplément), 1.

Legrand, P. \& Nabos, G. 1962. Contribution à la stratigraphie du Cambro-Ordovicien dans le bassin saharien occidental. Bulletin de la Société géologique de France 7(4), 123-131.

MAREK, L. \& HAVLíčEK, V. 1967. The articulate brachiopods of the Kosov Formation (upper Ashgillian). Věstnik Ústředního ústavu geologického 42, 275-284.

Massa, D., Havlíček, V. \& Bonnefous, J. 1977. Stratigraphic and faunal data on the Ordovician of the Rhadames Basin (Libya and Tunisia). Bulletin des Centres de Recherches Exploration-Production Elf-Aquitaine 1(1), 3-27.

Matthew, G.F. 1895. Traces of the Ordovician System on the Atlantic coast. Royal Society of Canada, Transactions (series 1, section 4) 1, 253-279.

M'Coy, F. 1851. On some new Cambro-Silurian fossils. Annals and Magazine of Natural History 8(47), 387-409. DOI 10.1080/03745486109494991

Menchikoff, N. 1933. La série primaire de la Saoura et des chaînes d'Ougarta. Bulletin du Service de la Carte géologique d'Algérie 11, 109-123.

Menke, C.T. 1828. Synopsis methodica molluscorum generum omnium et specierum earum quae in Museo Menkeano adservantur. 91 pp. G. Uslar, Pyrmonti.

Mergl, M. 1983. New brachiopods (Cambrian - Ordovician) from Algeria and Morocco (Mediterranean Province). Ćasopis pro mineralogii a geologii 28(3), 337-352.

Moore, R.C. 1952. Brachiopods, 197-267. In Moore, R.C.,
LAlicker, C.G. \& Fisher, A.G. (eds) Invertebrate Fossils. McGraw-Hill, New York.

Moore, R.C. (ed.) 1965. Treatise on Invertebrate Paleontology. Part H, Brachiopoda. Volume 2, H523-H925. Geological Society of America \& University of Kansas Press, New York \& Lawrence.

ÖPIK, A. 1934. Über Klitamboniten. Universitatis Tartuensis (Dorpatensis) Acta et Commentationes (series A) 26(5), $1-239$.

Popov, L.E., Cocks, L.R.M. \& Nikitin, I.F. 2002. Upper Ordovician brachiopods from the Anderken Formation, Kazakhstan: their ecology and systematics. Bulletin of the British Museum (Natural History), Geology Series 58, 13-79.

Popov, L.E., Hairapetian, V., Evans, D.H., Ghobadi Pour, M., Holmer, L.E. \& BAARS, C. 2015. Review of the Ordovician stratigraphy and fauna of the Anarak Region in Central Iran. Acta Geologica Polonica 65, 403-435.

DOI 10.1515/agp-2015-0019

Poueyto, A. 1950. Coupe stratigraphique des terrains gothlandiens à graptolites au N. d'Ougarta (Sahara occidental) Comptes rendus sommaires de la Société géologique de France 3, 44-46.

Poueyto, A. 1951. Contribution à l'étude des terrains paléozoiques de la basse Daoura (Sahara occidental). Comptes rendus sommaires de la Société géologique de France 10, $156-157$.

Poueyto, A. 1952. Rhyolites et Grès d'Ougarta, Terrains Gothlandiens, 25-47. In Alimen, H., Le Maître, D., Menchikoff, N., Petter, G. \& Poueyto, A. (eds) Les Chaînes d'Ougarta et la Saoura, Monographies Régionales 15. XIX Congrès Géologique International, Alger.

Roch, E. 1933. Sur deux gisements fossilifères dans les Grès d'Ougarta (Confins algèro-marocains du Sud). Comptes rendus sommaires de la Société géologique de France 3 , 30-31.

Rouault, M. 1850. Note preliminaire sur une nouvelle formation decouverte dans le terrain silurien inferieur de la Bretagne. Bulletin de la Société géologique de France 7(2), 724-744.

Rozman, Kh.S. 1969. Pozdneordovikskiye Brakhiopody Sibirskoi Platformy. Paleontologicheskii Zhurnal 1969(3), 86108. [in Russian]

Savage, N.M., Mancenido, M.O., Owen, E.F., Carlson, S.J., Grant, R.E., Dagys, A.S. \& Sun, D. 2002. Rhynchonellida, 1027-1376. In Kaesler, R.L. (ed.) Treatise on Invertebrate Paleontology, Part H, Brachiopoda, (revised), 4, Rhynchonelliformea (part). Geological Society of America \& Kansas University Press, Boulder, Colorado \& Lawrence.

Schmidt, H. 1965. Neue Befunde an Paläozoischen Rhynchonellacea (Brachiopoda). Senckenbergiana Lethaea 46, $1-25$.

Schuchert, C. 1893. Classification of the Brachiopoda. American Geologist 11, 141-167.

Schuchert, C. 1913. Class 2. Brachiopoda, 355-420. In Zittel, K.A. von (ed.) Textbook of Palaeontology, Vol. 1. Second edition. MacMillan, London.

Schuchert, C. \& Cooper, G.A. 1931. Synopsis of the brachiopod genera of the suborders Orthoidea and Pentameroidea, with 
notes on the Telotremata. American Journal of Science 22, 241-251. DOI 10.2475/ajs.s5-22.129.241

Schuchert, C. \& Cooper, G.A. 1932. Brachiopod genera of the suborders Orthoidea and Pentameroidea. Memoirs of the Peabody Museum of Natural History 4, 1-270.

Temple, J.T. 1965. Upper Ordovician brachiopods from Poland and Britain. Acta Palaeontologica Polonica 10, 379-450.

Termier, H. \& Termier, G. 1950. Paléontologie marocaine. Tome II: Invertébrés de l'Ere primaire, Bryozaires et Brachiopodes, fascicule II. Actualités Scientifiques et Industrielles 1093, $1-253$.

Torsvik, T.H. \& Cocks, L.R.M. 2011. The Palaeozoic palaeogeography of central Gondwana. Geological Society London, Special Publications 357, 137-166. DOI 10.1144/SP357.8

Torsvik, T.H., Van der Voo, R., Preeden, U., Mac Niocaill, C., Steinberger, B., Doubrovine, P.V., van Hinsbergen, D.J., Domeier, M., Gaina, C., Tohver, E. \& Meert, J.G. 2012. Phanerozoic polar wander, palaeogeography and dynamics. Earth-Science Reviews 114, 325-368.

DOI 10.1016/j.earscirev.2012.06.007

Ulrich, E.O. \& Cooper, G.A. 1936. New genera and species of Ozarkian and Canadian brachiopods. Journal of Paleontology 10, 616-631.

Ulrich, E.O. \& CoOPER, G.A. 1942. New genera of Ordovician brachiopods. Journal of Paleontology 16, 620-626.

Villas, E. 1985. Braquiópodos del Ordovícico Medio y Superior de las Cadenas Ibéricas Orientales.Memorias del Museo Palaeontologico de la Universidad de Zaragoza 1(1-2), $1-22$.

Villas, E., Álvarez, L.S. \& Gutiérrez-Marco, J.C. 1998. First

Appendix. Fossil localities.

Locality PH137 [10 m NW of the point PH 237]. Djebel Serraf Formation (Hirnantian), vicinity of Ougarta Village; Glosellininae gen. et sp. indet. 1, Hirnantia saggitifera (M'Coy, 1851).

Locality PH237 [02 $\left.12^{\circ} 16^{\prime} 45^{\prime \prime} \mathrm{W}, 29^{\circ} 39^{\prime} 36^{\prime \prime} \mathrm{N}\right]$. Djebel Serraf Formation (Hirnantian), vicinity of Ougarta Village; ?Libyaeglossa sp., Hirnantia saggitifera (M'Coy, 1851), Plectothyrella crassicostis chauveli Havlíček, 1971.

Locality PH237-bis [0.10 m below PH 237]. Djebel Serraf Formation (Hirnantian), vicinity of Ougarta Village; ?Libyaeglossa sp., Plectothyrella crassicostis chauveli Havlíček, 1971.

Locality PH450-451 [02०01' 18 ", W, 29 30' 32" N]. Djebel Serraf Formation (Hirnantian Foum El Kseib; Hirnantia saggitifera (M'Coy, 1851).

Locality PH464 [02 37' 02" W, $\left.29^{\circ} 28^{\prime} 22^{\prime \prime} \mathrm{N}\right]$. Bou M'Haoud Formation, Upper Member (middle Katian), vicinity of Bou M'Haoud; Drabovia sp.

Locality PH465-bis [the same section as PH464; $1.25 \mathrm{~m}$ above PH464]. Bou M'Haoud Formation, Upper Member (middle Katian), vicinity of Bou M'Haoud; Drabovia sp.

Locality PH466 [the same section as PH464; $8.25 \mathrm{~m}$ above PH464]. Bou M'Haoud Formation, Upper Member (mid- record of a Hirnantia Fauna from Spain, and its contribution to the Late Ordovician palaeogeography of northern Gondwana. Earth and Environmental Science Transactions of The Royal Society of Edinburgh 89, 187-197.

DOI 10.1017/S0263593300007124

WaAgen, W. 1885. Salt Range Fossils. I. Productus-Limestone fossils. Geological Survey of India, Memoirs, Palaeontologia Indica, Series 13(4), 729-770.

Walcott, C.D. 1912. Cambrian Brachiopoda. United States Geological Survey Monograph, 51. Part 1, 872 pp.; Part 2, 379-450.

Williams, A. \& Curry, G.B. 1985. Lower Ordovician Brachiopoda from the Tourmakeeady Limestone, Co Mayo, Ireland. Bulletin of the British Museum (Natural History), Geology 38, 183-269.

Williams, A. \& Harper, D.A.T. 2000. Orthida, 714-782. In KAESLER, R.L. (ed.) Treatise on Invertebrate Paleontology, Vol. $H$, Brachiopoda 3 (revised). Geological Society of America \& Kansas University Press, Boulder, Colorado \& Lawrence.

Williams, A., Carlson, S.J., Brunton, C.H.C., Holmer, L.E. \& Popov, L.E. 1996. A supra-ordinal classification of the Brachiopoda. Philosophical Transactions of the Royal Society: Biological Sciences 35, 1171-1193.

Wolfart, R., Bender, F. \& Stein, V. 1968. Stratigraphie und Fauna des Ober-Ordoviziums (Caradoc-Ashgill) und UnterSilurs (Unter-Llandovery) von Südjordanien. Geologisches Jahrbuch 85, 517-564.

Woodward, S.P. 1852. A Manual of the Mollusca; or, a Rudimentary Treatise of Recent and Fossil Shells. xvi +486 pp. John Neale, London.

dle Katian), vicinity of Bou M'Haoud; Drabovia sp., Drabovinella maxima Mergl, 1983, ?Hirnantia sp. 2.

Locality PH467 [the same section as PH464; $15 \mathrm{~m}$ above PH464]. Bou M'Haoud Formation, Upper Member (middle Katian), vicinity of Bou M'Haoud; Drabovia sp., Drabovinella maxima Mergl, 1983.

Locality PH468 [the same section as PH464; $21.25 \mathrm{~m}$ above PH464]. Bou M'Haoud Formation, Upper Member (middle Katian), vicinity of Bou M'Haoud; Drabovia sp., Svobodaina cf. havliceki Villas, 1985.

Locality PH1775 [N-W d'Hassi Talamt]. Bou M'Haoud Formation (upper Sandbian-lower Katian); isolated outcrop of fine-grained sandstones at northern limb of Erg Chebbi; Drabovinella regia Havlíček, 1971.

Locality PH1780 [02 $\left.2^{\circ} 12^{\prime} 15^{\prime \prime} \mathrm{W}, 29^{\circ} 30^{\prime} 32^{\prime \prime} \mathrm{N}\right]$. Djebel Serraf Formation, Outgarta, Ksar Sandstone Upper Member (Hirnantian), Foum El Kseib; ?Leptaena sp.

Locality PH1791 [02 02' $\left.09^{\prime \prime} \mathrm{W}, 2^{\circ} 2^{\circ} 5^{\prime} 03^{\prime \prime} \mathrm{N}\right]$. Foum ez Zeidiya Formation, Foum opposite Zmeïlet el Barka; Tissintia convergens Havlíček, 1970.

Locality PH1796 [about 2.50 m below PH 1797]. Bou M'Haoud Formation Lower Member (upper Sandbian-lower Katian), Foum opposite Daïet en Nouguir; ?Hirnantia sp. 1. 
Locality PH1797 [02 00' 07" W, 29 24' 11" N]. Bou M'Haoud Formation, Lower Member (upper Sandbian-lower Katian), Foum opposite Daïet en Nouguir; ?Hirnantia sp. 1.

Locality PH1801 [02 $\left.02^{\prime} 17^{\prime \prime} \mathrm{W}, 29^{\circ} 26^{\prime} 56^{\prime \prime} \mathrm{N}\right]$. Bou M'Haoud Formation, Lower Member (upper Sandbian-lower Katian), height 472 m; Drabovia cf. tenuiseptata Havlíček, 1971.

Locality PH1802 [6.5 m above PH1801]. Bou M'Haoud Formation, Lower Member (upper Sandbian-lower Katian), height 472 m; Drabovia cf. tenuiseptata Havlíček, 1971, ?Fehamya sp.

Locality PH1807 [02 14' 25" W, 29 30' 51" N]. Bou M'Haoud Formation, Lower Member (upper Sandbian-lower Katian), Foum El Kseib; Orbiculothyris cf. costellata Wolfart, 1968.

Locality PH1812 [02 $\left.12^{\circ} 12^{\prime} 37^{\prime \prime} \mathrm{W}, 29^{\circ} 30^{\prime} 45^{\prime \prime} \mathrm{N}\right]$. Djebel Serraf Formation (Hirnantian), Foum El Kseib; Hirnantia saggitifera (M'Coy, 1851).

Locality PH1821 [02 $\left.22^{\circ} 55^{\prime \prime} \mathrm{W}, 2^{\circ} 22^{\prime} 55^{\prime \prime} \mathrm{N}\right]$. Kheneg el Aatène Formation, Upper Member (upper Dapingian), Mesdar; Lingulobolus sp.

Locality PH1822 [some meters above PH1821]. Kheneg el Aatène Formation, (upper Dapingian), Mesdar; Lingulobolus sp.

Locality PH1828 [02 $\left.{ }^{\circ} 16^{\prime} 47^{\prime \prime} \mathrm{W}, 2^{\circ} 32^{\prime} 80^{\prime \prime} \mathrm{N}\right]$. Foum ez Zeidiya Formation (upper Darriwilian), Kheneg el Aatène; Tissintia convergens Havlíček, 1970.

Locality PH1829 [30 m above the point: $02^{\circ} 37^{\prime} 00^{\prime \prime} \mathrm{W}, 29^{\circ} 27^{\prime}$ $\left.05^{\prime \prime} \mathrm{N}\right]$. Foum ez Zeidiya Formation (upper Darriwilian), Bou M'Haoud Ravine; Tissintia convergens Havlíček, 1970.

Locality PH1832 [02 39' 28" W, 29 55' 9" N]. Bou M'Haoud Formation, Lower Member (upper Sandbian-lower Katian), Kheneg et Tlaïa; Drabovinella regia Havlíček, 1971.

Locality PH1834 [4 $\mathrm{m}$ above $02^{\circ} 39^{\prime} 28^{\prime \prime} \mathrm{W}, 29^{\circ} 55^{\prime} 9^{\prime \prime} \mathrm{N}$ ]. Bou M'Haoud Formation, Middle Member (lower Katian), Kheneg et Tlaïa; Drabovia cf. tenuiseptata Havlíček, 1971.

Locality PH1836 [ $3 \mathrm{~m}$ above the point $02^{\circ} 39^{\prime} 22^{\prime \prime} \mathrm{W}, 29^{\circ} 52^{\prime}$ 06" N]. Bou M'Haoud Formation, Middle Member (lower Katian), Kheneg et Tlaïa; Drabovia tenuiseptata Havlíček, 1971, Rostricellula ambigena (Barrande, 1847), Tafilaltia destombesi Havlíček, 1971.

Locality PH1837 [18 m below the beds of marble sanstones]. Bou M'Haoud Formation, Middle Member (lower Katian), Bou M'Haoud Ravine; Camerellainae gen. et sp. indet.

Locality PH1841 [02 $\left.32^{\circ} 36^{\prime} 40^{\prime \prime} \mathrm{W}, 29^{\circ} 28^{\prime} 14^{\prime \prime} \mathrm{N}\right]$. Bou M'Haoud Formation, Upper Member (middle Katian), Bou M'Haoud Village; Drabovia sp., Drabovinella maxima Mergl, 1983.

Locality PH1842 [02 $\left.16^{\prime} 54^{\prime \prime} \mathrm{W}, 2^{\circ} 38^{\prime} 15^{\prime \prime} \mathrm{N}\right]$. Djebel Serraf Formation (Hirnantian) of Ougarta Village; Plectothyrella crassicostis chauveli Havlíček, 1971.

Locality PH1852 [5 $\mathrm{m}$ above the point PH 1828]. Foum ez Zeidiya Formation (upper Darriwilian), Kheneg el Aatène; Tissintia convergens Havlíček, 1970.

Locality PH1854 [near 02 39' 6" W, 29 51' 46" N]. Foum ez Zeidiya Formation (upper Darriwilian), Kheneg et Tlaïa; Tissintia convergens Havlíček, 1970.

Locality PH1855 [same bed as PH1832]. Bou M'Haoud Formation, Lower Member (upper Sandbian-lower Katian), Kheneg et Tlaïa; Drabovia cf. tenuiseptata Havlíček, 1971, Drabovinella regia Havlíček, 1971.
Locality PH1856 [same bed as PH1836]. Bou M'Haoud Formation, Middle Member (lower Katian), Kheneg et Tlaïa; Drabovia cf. tenuiseptata Havlíček, 1971, Rostricellula ambigena (Barrande, 1847).

Locality PH1859 [02 $\left.02^{\circ} 38^{\prime} 03^{\prime \prime} \mathrm{W}, 2^{\circ} 30^{\prime} 45^{\prime \prime} \mathrm{N}\right]$. Top of the marble sandstones, Bou M'Haoud Formation, Lower Member (upper Sandbian-lower Katian), area NW of Bou M'Haoud; Drabovinella regia Havlíček, 1971.

Locality PH1860 [02 33' 22" W, 2950' 49" N]. Bou M'Haoud Formation, Middle Member (lower Katian), Kheneg et Tlaïa; Mezotreta sp., Orbiculothyris cf. costellata Wolfart, 1968 in Wolfart et al. (1968), Rostricelula ambigena (Barrande, 1847), Tafilaltia destombesi Havlíček, 1971.

Locality PH1861 [02 33' 20" W, 29²8'09" N]. Bou M'Haoud Formation, Middle Member (lower Katian), Kheneg et Tlaïa; Rostricelula ambigena (Barrande, 1847). Ougarta Village.

Locality SQ449 [Ksar d'Ougarta]. Djebel Serraf Formation (Hirnantian), Ougarta Village; Plectothyrella crassicostis chauveli Havlíček, 1971.

Locality SQ450 [Ksar d'Ougarta]. Djebel Serraf Formation (Hirnantian), Ougarta Village; Plectothyrella crassicostis chauveli Havlíček, 1971.

Locality SY350 [01 $\left.23^{\circ} 48^{\prime \prime} \mathrm{W}, 2^{\circ} 25^{\prime} 19^{\prime \prime} \mathrm{N}\right]$. Foum ez Zeidiya Formation, Lower Member (lower Darriwilian) at Feidj ez Zeidiya; ?Sivorthis fraterna (Havlíček, 1971).

Locality SY351 [0.10 m above PH350]. Foum ez Zeidiya Formation, Lower Member (lower Darriwilian) at Feidj ez Zeidiya; ?Sivorthis fraterna (Havlíček, 1971).

Locality SY352 [0.30 m above PH350]. Foum ez Zeidiya Formation (lower Darriwilian) at Feidj ez Zeidiya; ?Sivorthis fraterna (Havlíček, 1971).

Locality SY 499 [?SW end of the Foum: 02 $00^{\prime} 05^{\prime \prime} \mathrm{W}, 29^{\circ} 24^{\prime}$ $\left.19^{\prime \prime} \mathrm{N}\right]$. Foum ez Zeidiya Formation (upper Darriwilian), (?) Foum opposite Daïet en Nouguir; Tissintia convergens Havlíček, 1970.

Locality SY606 [02 00' 52" W, 29 31'36" N]. Djebel Serraf Formation (Hirnantian Foum El Kseib; Plectothyrella crassicostis chauveli Havlíček, 1971.

Locality SY609 [02 $\left.12^{\prime} 15^{\prime \prime} \mathrm{W}, 29^{\circ} 30^{\prime} 32^{\prime \prime} \mathrm{N}\right]$ Djebel Serraf Formation (Hirnantian), Foum El Kseib; Hirnantia saggitifera (M'Coy, 1851).

Locality SY636 [02 $37^{\prime} 00^{\prime \prime}$ W, $29^{\circ} 28^{\prime} 09^{\prime \prime}$ N]. Bou M'Haoud Formation, Upper Member (middle Katian), Bou M'Haoud Village; Drabovia sp., Drabovinella maxima Mergl, 1983.

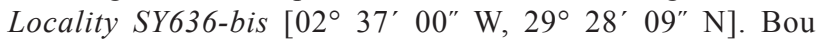
M'Haoud Formation, Upper Member (middle Katian), Bou M'Haoud Village; Drabovia sp.

Locality SY639 [02 $\left.36^{\prime} 15^{\prime \prime} \mathrm{W}, 29^{\circ} 28^{\prime} 09^{\prime \prime} \mathrm{N}\right]$. Bou M'Haoud Formation Upper Member (middle Katian), Bou M'Haoud Village; Orbiculothyris cf. costellata Wolfart, 1968; Drabovia sp.

Locality SY640 [= PH 466]. Bou M'Haoud Formation, Upper Member (middle Katian), Bou M'Haoud Village; Drabovia sp., Drabovinella maxima Mergl, 1983.

Locality SY644 [02 $\left.12^{\prime} 00^{\prime \prime} \mathrm{W}, 2^{\circ} 31^{\prime} 36^{\prime \prime} \mathrm{N}\right]$. Bou M'haoud Formation, Lower Member (upper Sandbian-lower Katian), Foum Tinneslem; Drabovinella regia Havlíček, 1971.

Locality SY645 [4.5 m above SY 644]. Bou M'Haoud Formation, Lower Member (upper Sandbian-lower Katian), Foum Tinneslem; Drabovinella regia Havlíček, 1971. 